Canadian Journal of Fisheries and Aquatic Sciences Journal canadien des sciences halieutiques et aquatiques

\title{
Guilty as charged: Nile perch was responsible for the decline of haplochromines in Lake Victoria
}

\begin{tabular}{|r|l|}
\hline Journal: & Canadian Journal of Fisheries and Aquatic Sciences \\
\hline Manuscript ID & cjfas-2017-0056.R2 \\
\hline Manuscript Type: & Discussion \\
\hline Date Submitted by the Author: & 06-Nov-2017 \\
\hline $\begin{array}{r}\text { Complete List of Authors: } \\
\text { Is the invited manuscript for } \\
\text { consideration in a Special } \\
\text { Issue? : }\end{array}$ & N/A \\
\hline Keyword: & $\begin{array}{l}\text { Lake Victoria, haplochromines, Nile perch, EUTROPHICATION < General, } \\
\text { CLIMATE CHANGE < General }\end{array}$ \\
\hline &
\end{tabular}




\title{
GUILTY AS CHARGED: NILE PERCH WAS THE CAUSE OF THE HAPLOCHROMINE DECLINE IN LAKE VICTORIA
}

\author{
BRIAN E. MARSHALL \\ Department of Biological sciences, University of Zimbabwe, Harare \\ and \\ Lake Victoria Fisheries Organization, Jinja, Uganda ${ }^{1}$ \\ ${ }^{1}$ Present address: 9/4074 Great North Road, Auckland 0602, New Zealand.
}

E-mail: brian.marshal101@gmail.com

Telephone: +6498184790

Fax: none

No. of words: 17321

No. of figures: 8

No. of tables: 11 


\title{
GUILTY AS CHARGED: NILE PERCH WAS RESPONSIBLE FOR THE DECLINE OF HAPLOCHROMINES IN LAKE VICTORIA
}

\begin{abstract}
Debate on the contribution of Nile perch (Lates niloticus) to the demise of Lake Victoria's 500+ endemic haplochromine cichlids centres around the "top-down" and "bottom-up" hypotheses. The former suggests Nile perch destroyed the haplochromines causing the disruption of food chains and nutrient cycling so initiating the accelerated eutrophication of the lake. The latter proposes that haplochromines suppressed Nile perch by preying on its eggs and fry, or competing with juveniles for food. A recent paper argued that accelerated eutrophication caused by a climatic event led to their collapse, allowing Nile perch to explode. However, the Nile perch population grew before haplochromines decreased and they only collapsed once Nile perch biomass exceeded theirs. The chronology indicates that accelerated eutrophication of the lake followed rather than preceded the haplochromine collapse suggesting that eutrophication was not its cause. A size-selective predation model developed to support the bottom-up hypothesis is discussed in light of existing data but does not support the bottom-up hypothesis. It was concluded that the top-down model better fits the data and conforms to the law of parsimony.
\end{abstract}




\section{Introduction}

Nile perch Lates niloticus in Lake Victoria (Figure 1) is the quintessential invasive species, having been introduced 60 years ago by colonial officials in Uganda who overrode scientific advice and the concerns of their colleagues in Kenya and Tanzania (Jackson 2000; Pringle 2005). The consequences only became apparent after its population exploded around 1980 and two significant changes occurred in the lake. The first was the apparent extirpation of its native fishes, notably the 500+ endemic haplochromine cichlid species (Barel et al. 1985; Ogutu-Ohwayo 1990a; Witte et al. 1992), an event described as the greatest vertebrate extinction of recent times (Kaufman 1992). The second was the lake's relatively abrupt change from an oligotrophic-mesotrophic system to a eutrophic one, marked by the development of blue-green algal blooms, anoxia and fish kills (Ochumba 1988, 1990; Ochumba and Kibaara 1989; Hecky 1993; Hecky et al. 1994). Early workers attributed these changes to a "top-down" series of cascading effects that followed the loss of both biomass and diversity within and between trophic levels as a result of the haplochromine extirpation. This was assumed to have broken down the complex food chains and nutrient recycling pathways that previously existed in the lake, making nutrients available for algal blooms (Barel et al. 1985; Payne 1987; Achieng 1990; Ligtvoet and Witte 1991; Kaufman 1992; Goldschmidt et al. 1993; Gophen et al. 1995).

Over the years there has been considerable debate over this question, beginning with Bundy and Pitcher (1995) who suggested that Nile perch may not have been solely responsible for this situation. A review of the impacts of eutrophication on Lake Victoria fishes, concluded that the haplochromine decline was caused by Nile perch (Witte et al. 2005), but it was later suggested that it was not possible to separate the effects of Nile perch and eutrophication since both occurred in the same time period (Witte et al. 2007a, 2013). Other authors have argued that "bottom-up" influences are a more valid explanation for the 
46 changes in Lake Victoria, with Nile perch being just one of a multiplicity of stressors

47 (Kolding et al. 2008; Hecky et al. 2010).

Hecky et al. (2010) suggested that the transition to a new ecosystem state, with a

highly productive algal community and dramatically altered food webs, may have been

triggered by a period of low wind stress, along with climate warming during the 1970s. This approach culminated in a recent paper in this journal which questioned whether Nile perch was the cause or a consequence of the haplochromine decline (van Zwieten et al. 2016).

53 These authors argued that haplochromines suppressed the growth of the Nile perch population, and an external event was needed to reduce their numbers and allow the Nile perch population to grow. This event was a period of low wind stress from 1976 to 1983 that was said to have triggered eutrophication and increased anoxia, leading to the demise of the haplochromines and allowing the Nile perch population to explode.

If this is correct, it would mean that Lake Victoria could be one of the first examples of a whole-ecosystem change brought about by recent climatic events. This would certainly be of significance in the present era of rapid climate change and merits further discussion.

\section{The fish and fisheries of Lake Victoria}

The most important characteristic of Lake Victoria's fish community was its astonishingly diverse community of haplochromine cichlids. The exact number of species is unknown but estimates have risen from around 150 species in 1970 to $500+$ in 2000 (Witte et al. 2007). They are small fish, mostly around 6-10 $\mathrm{cm}$ in length with a few species reaching 15-17 cm (Witte and van Oijen 1990, 1995) and they display an extraordinary range of trophic specialisations. At least 16 major trophic categories have been identified with further specialisations within each of them. Very little is known about the ecology of these fish, the interactions between species, their role in the Lake Victoria ecosystem or even their 
71 distribution in the lake. Because of their small size, the difficulties in identification, and the

72 large numbers involved, most fishery surveys (historically and presently) simply lump them together as "haplochromines" without separating the species. The exception to this is the work of the Haplochromine Ecology Survey Team in the Mwanza Gulf, Tanzania (Witte and van Densen 1995) who described the community structure and the rapid changes associated with a trawl fishery and Nile perch. Thus, while there is a considerable amount of information about the post-Nile perch situation, at least in the Mwanza Gulf, almost nothing is known about the haplochromine community structure anywhere in the lake before the Nile perch introduction. Assumptions about the pre-Nile perch situation should therefore be treated with caution.

About 40 non-haplochromine species also occurred in the lake. Two cichlids, the tilapias Oreochromis esculentus and $O$. variabilis, were the target of the commercial gill-net fishery that began in 1908 and their stocks were rapidly depleted in intensively -fished areas. In the Nyanza Gulf, Kenya, for instance, the catch of $O$. esculentus fell from 25 fish per net in 1908 to 8 in 1920, 2 in 1940 and 0.5 in 1970 (Kudhongania and Chitamwebwa 1995) while in Pilkington Bay, Uganda, the catch in 4-inch nets fell from an average of 15 fish per net in 1955 to one fish per net in 1957 (EAFFRO 1958). Several non-native tilapias were introduced into the lake in the 1950s in an effort to restore this fishery (Welcomme 1964) but only one of them, the Nile tilapia $O$. niloticus, became important in the fishery, and then only after the Nile perch explosion (Goudswaard et al. 2002). colonial officials considered them to have little value. Proposals were made to utilise them for fish meal and a commercial trawl fishery was eventually established in the Mwanza Gulf for this purpose in 1973. Maintaining the tilapia fishery seems to have been the main management priority during the 1970s. Discussions about the state of the Lake Victoria 
96 fisheries centred around the need to maintain this fishery, with Nile perch only being

97 mentioned as a potential threat to tilapias rather than haplochromines (e.g. Fryer 1972, 1973a, 1973b; Worthington, 1972; Jackson 1973; Stoneman et al. 1973). A proposal to target predators such as Clarias, Bagrus and Protopterus in order to improve tilapia catches, made no mention of Nile perch (Marten 1979a) even though they were increasingly being taken in commercial fisheries at the time (Okedi 1970; Achieng 1990). It is regrettable that Nile perch was not investigated more thoroughly at that time as this might have prevented subsequent controversies over the sequence of events.

\section{Nile perch growth and haplochromine decline}

It is unclear when Nile perch were introduced into Lake Victoria but some were caught in 1960, before the official introductions in 1962 and 1963 (Gee 1964). These may have been introduced surreptitiously by the Uganda Wildlife Service (Pringle 2005). Its subsequent population growth conformed to the population growth depicted in any elementary ecology textbook, an S-shaped logistic curve with three phases: establishment, expansion and stability (Shigesada et al. 1995). This can be most easily seen in the northern part of the lake (Uganda and Kenya), where it where it was introduced and first became numerous (Kudhongania and Cordone 1974).

\section{Establishment Phase (Kenya and Uganda)}

This phase lasted for about 20 years and its length is most probably explained by introduction effort, a critically important factor in the establishment of introduced species (Jeschke and Strayer 2005; Lockwood et al. 2005; Simberloff 2009). The official introductions consisted of 35 fish ranging from 16.0-43.5 cm in length in May 1962, followed by 339 fingerlings in September 1963 (all from Lake Albert) and eight fish from Lake Turkana in 1963, giving a total of 382 fish (Gee 1964). The extent of post-introduction 
122 mortality is unknown, and the number of survivors may have been lower than this. The 123 number introduced before this time is unknown (Pringle 2005) but doubling the official 124 number gives a total of 764 fish, a very small number of fish for such a large lake. It is not

125 surprising that it took some time for the population to build up.

Nevertheless, the East African Freshwater Fisheries Organisation (EAFFRO) knew by 1963 that Nile perch were breeding in the lake and surveys revealed that they were dispersing along its northern shores (Anon. 1964, 1966). The number brought to the Massesse Fish Market in Jinja (Uganda) increased exponentially, from a monthly average of 32 in 1963, to 62 in 1964 and 195 in 1965. The Nile perch population in the area serving the market was said to have increased by between 500\% and 700\% in 1964 (Gee 1965).

From 1964 to 1967 almost all the Nile perch brought into the market were about one year old, further confirming the establishment of a breeding population (Table 1). Older fish then began to appear in the market and from 1970 to 1977 the catch was dominated by fish aged from 6-10 years. At this time, fishermen began targeting the more profitable large fish by switching to large-meshed gill nets (Acere 1988) and this may not reflect a failure of recruitment. This was confirmed by Okedi (1970) who sampled commercial catches and found the smallest Nile perch were $21.0 \mathrm{~cm}$ (males) and $18.5 \mathrm{~cm}$ (females) in length; these fish would have been about 5-6 months old (Hughes 1992). The shift back to one-year old fish, that began in 1976 (Table 1), may reflect either an increase in their numbers or a decrease in large individuals just before the expansion phase began.

Nile perch made up $0.04 \%$ of the catch from an early bottom trawl survey carried out in Uganda in 1966 (Gee and Gilbert 1967) and this proportion increased three-fold to $0.12 \%$ in Ugandan waters during the lake-wide 1969-71 survey (Kudhongania and Cordone 1974). This survey estimated that the standing stock of Nile perch in the lake as a whole was $402 \mathrm{t}$ of which 385 t (97\%) was in Kenya and Uganda. The total weight of the fish that were 
147

148

149

150

151

152

153

154

155

156

157

158

159

160

161

162

163

164

165

166

167

168

169

170

171

introduced is not known, but if the 339 fingerlings weighed $10 \mathrm{~g}$ each then their total weight would have been less than $4 \mathrm{~kg}$ while the $43.5-\mathrm{cm}$ fish, the largest one introduced, would have weighed about $1.0 \mathrm{~kg}$ (Hughes 1992). Consequently, no more than 20-30 kg of fish might have been introduced and thus the biomass of Nile perch in 1969-71 had increased by at least four orders of magnitude since their introduction.

\section{Expansion phase (Kenya and Uganda)}

This explosive phase began in the northern waters of the lake around 1980-81. In Uganda, the Nile perch catch rate rose from $0.5 \mathrm{~kg} \mathrm{hour}^{-1}$ in the $1969-71$ trawls to $3.5 \mathrm{~kg}$ hour $^{-1}$ in 1981, an increase of $700 \%$ (Table 2). This was followed by an increase from 3.5 to $234.7 \mathrm{~kg}$ hour $^{-1}$ between 1981 and 1985, representing an average increase of 1,600\% per annum. The haplochromine biomass rose slightly between 1969-71 and 1981 but it did not double, as stated by van Zwieten et al. (2016; p. 627). It fell from $391.7 \mathrm{~kg} \mathrm{hour}^{-1}$ in 1981 to $264.6 \mathrm{~kg}_{\text {hour }}{ }^{-1}$ in 1983 , a $48 \%$ decrease, followed by a collapse to zero in 1986 . The biomass of other species declined from 1982 onwards, with the most rapid collapse beginning in 1984 when the biomass of Nile perch exceeded that of all other species.

The situation was similar in Kenya, where the biomass of Nile perch came to exceed that of all other species between 1977 and 1982 leading to a collapse in the haplochromines (Table 3). These findings are supported by data from commercial fisheries, where landings increased exponentially, from $17 \mathrm{t}$ in 1969 to 68,000 $\mathrm{t}$ in 1988 (Figure 2). Fish catches may of course be influenced by fishing effort, but the catch per unit effort increased steadily from 1980 to 1990 indicating that this was a real population increase. In contrast, the haplochromine catches increased slightly from 6,400 t in 1969 to 6,600 t in 1979, after which they fell to zero in 1984. This collapse began in 1980 once the catch, and by implication the biomass, of both haplochromines and Nile perch were about equal. 
172

173

174

175

176

177

In both countries the tipping-point seems to have been reached when the Nile perch biomass equalled that of its prey, which were then unable to sustain their own populations. Thus, the fish communities in the lake changed catastrophically from a seemingly stable haplochromine-dominated state to one dominated by Nile perch. As Scheffer et al. (2001) point out, such catastrophic changes can occur unannounced with 'early-warning signals' being difficult to obtain. They also noted that sudden change could occur once an ecosystem lost resilience, which they define as the maximum perturbation a system can withstand without shifting to an alternative stable state. The early warning signal in Lake Victoria, the steady increase in the Nile perch population, seems to have been overlooked.

\section{Stabilisation phase (Kenya and Uganda)}

The haplochromine collapse appears to have marked the end of the Nile perch expansion phase, but whether this resulted in a 'stable' condition is debatable. The Nile perch population might have been expected to collapse once its principal food source was exhausted, but it survived because alternative food sources became available. The most important of these were the atyid shrimp Caridina nilotica and the endemic sardine-like cyprinid Rastrineobola argentea ('dagaa'), while cannibalism was frequent. The total catch of Nile perch peaked at around 300,000 $\mathrm{t}$ in 1990-91 and subsequently levelled off around 250,000 t per annum, obtained from a biomass fluctuating around one million tonnes (TaabuMunyaho et al. 2016). It has been suggested that that Lake Victoria could have supported a larger Nile perch biomass (van Zwieten et al. 2016) but this is questionable given the high incidence of cannibalism (Hughes 1986; Ogari and Dadzie 1988; Ogutu-Ohwayo 1990b) and the deterioration of their length-weight relationships and condition that followed the haplochromine collapse (Ogutu-Ohwayo 1999). 
Nile perch in Tanzania

The situation in Tanzania differed in that Nile perch were initially scarce, with an estimated biomass of only $7 \mathrm{t}$ in 1969-71 (Kudhongania and Cordone 1974). The expansion phase began later, evidently driven by sub-adult fish moving southwards from Kenya (Goudswaard et al. 2008). This movement is not well-documented but Nile perch accounted for $>50 \%$ of the catch in the Mara region (on the east coast south of the Kenya border) in 1984 and in the Mwanza region (south of Mara) in 1986 (Bwathondi 1990).

The growth of the fishery in Tanzania was similar to that in Uganda and Kenya, with explosive growth (4 orders of magnitude in 5 years) increasing the catches from about $270 \mathrm{t}$ in 1981 to 184,000 t in 1985 (Figure 3a). Haplochromine catches fluctuated but declined rapidly from about 24,000 t in1983 to $17,000 \mathrm{t}$ in 1986, to 1,500 t in 1987 and zero in 1988 . As in Kenya and Uganda the decline of the haplochromines in the commercial fishery began once the Nile perch catch exceeded that of all other species, a point reached in 1986 with the Nile perch catch being, 124,000 t compared to 79,000 $\mathrm{t}$ for all other species (Bwathondi 1990).

A unique situation developed in the Mwanza Gulf where a commercial trawl fishery had been established in 1973 to catch haplochromines for fish-meal, with 10 trawlers operating in the gulf by 1985 (Witte and Goudswaard 1985). The average catch rate in research trawls from 1975 to 1979 (excluding the very high 1976 value) was 1,236 kg hour ${ }^{-1}$ but the stock collapsed thereafter, falling to zero in 1988 (Figure 3b). All commercial trawling was suspended in 1987 (Goudswaard and Ligtvoet 1987) and it has never resumed. Nile perch first appeared in these catches in 1975, with catch rates of $1 \mathrm{~kg} \mathrm{hour}^{-1}$ until 1979 and $4 \mathrm{~kg}$ hour $^{-1}$ up to 1982 , after which they rose to a maximum of $203 \mathrm{~kg} \mathrm{hour}^{-1}$ in 1987 (Figure 3b). Although the biomass of Nile perch exceeded that of the haplochromines by 1986, the growth of the Nile perch population in the Mwanza Gulf was less explosive 
222 (only 2 orders of magnitude in 5 years) than elsewhere in Tanzania. Perhaps the growth of

223 this population may have been limited by a lack of food since the haplochromines had almost

224 collapsed before the expansion phase began. Shrimps only appeared in the bottom trawls in

225 1987, after the haplochromine collapse, when the maximum catch was 436 in a 10-minute

226 haul, although it exploded to 200,000 in 1988 (Goudswaard et al. 2006).

227

228

229

230

231

232

233

234

235

236

237

238

239

240

241

242

243

244

245

246

\section{The diet of Nile perch}

The sequence of events in the lake can be tracked by a consideration of the diet of Nile perch. Small ones $(1-5 \mathrm{~cm})$ fed mostly on zooplankton and midge larvae in shallow water $(<5 \mathrm{~m})$ but shifted to shrimps in deeper water (Katunzi et al. 2006). After the Nile perch explosion, the diet of fish $<20 \mathrm{~cm}$ in length consisted primarily of shrimps and other invertebrates, and shrimps remained important after the haplochromine recovery although piscivory increased (Table 4). Haplochromines had been an insignificant component of this size class diet in Tanzania in 1988-89 (Katunzi et al. 2006) and the shift reflected their continuing recovery.

The earliest record of Nile perch diet in Lake Victoria came from fish in the $20-40 \mathrm{~cm}$ size range caught in Uganda in 1964 (Figure 4). Their diet was varied with the major food items being haplochromines (37\%), tilapias and unidentified cichlids (33\%), mormyrids $(20 \%)$ and other fish species $(10 \%)$. Nile perch were established and expanding in the period 1968-77 and in Uganda fish in both the 20-40 $\mathrm{cm}$ and 40-60 $\mathrm{cm}$ size classes were feeding primarily on haplochromines with a small proportion of dagaa and other species. After the haplochromines collapsed, shrimps were the principal food item in both size classes in Kenya (1982-83), followed by smaller Nile perch and dagaa. By 1988, these were less important in Uganda where small Nile perch and dagaa were the major food items. There was no evidence of a haplochromine recovery in either country before 1988 . 
The collapse of the haplochromines was also clearly shown in the diets of fish from the Mwanza Gulf in Tanzania (Figure 4). Nile perch catches peaked in 1987 and although the diet in both size classes was predominantly haplochromines the appearance of cannibalism and dagaa suggests that these were beginning to decline. This was confirmed in 1988 and 1989 when the diet was dominated by shrimps, dagaa and Nile perch (especially in the 40-60 $\mathrm{cm}$ fish). Very few haplochromines were taken in those years but by $2006-08$ the haplochromine recovery made them once again an important component of Nile perch diet, notably in the larger fish.

There are few data on the diet of Nile perch $>60 \mathrm{~cm}$ in length. They were almost entirely cannibals in Kenya and Uganda during the 1980s (Hughes 1986; Ogari and Dadzie 1988; Ogutu-Ohwayo 1990b). In Tanzania, they fed mostly on haplochromines in 1986 (about $85 \%$ of the diet), with a sudden shift to dagaa and Nile perch in 1987 . By 1988 their diet consisted of juvenile Nile perch (40\%), dagaa (50\%) and other fish (10\%) (Mkumbo and Ligtvoet 1992). There are no recent data for fish in this size class but it may be assumed that their diet is similar to that of the $40-60 \mathrm{~cm}$ fish, with haplochromines being the major component.

\section{Ecological consequences: the eutrophication of Lake Victoria}

The cause of eutrophication, excessive nutrient loading resulting from population growth in the lake's basin (Verschuren et al 2002), is not disputed but there is some debate over its timing and the sequence of events. The 'eutrophication' of Lake Victoria is usually considered to be its relatively sudden transition in the mid-1980s from an oligotrophicmesotrophic condition to a eutrophic one, with the phytoplankton changing from a diverse community of diatoms, green and blue-green algae (Talling 1966, 1987) to one apparently dominated by colonial blue-greens such as Microcystis (Mugidde 1993). It is now known that 
272 eutrophication began much earlier than this but the evidence was invisible until revealed in

273 sediment cores in the 1990s (Hecky 1993; Verschuren et al. 2002; Stager et al. 2009; Hecky

274 et al. 2010). There is no indication that scientists working on the lake before the 1980 s were

275 concerned about eutrophication. Fryer's (1972) review of challenges facing the African Great

276 Lakes, for instance, only mentioned pollution as a future problem while Jackson (1973)

277 asserted that there was no evidence of future eutrophication or of organic oxygen-demanding

278 pollution in any of these lakes.

279 This is important because the literature on the impacts of eutrophication on Lake

280 Victoria is mostly based on events that occurred after the abrupt changes in the mid-1980s.

281 Knowledge of what occurred before then is entirely retrospective and the extrapolation of

282 present conditions backwards to the past should be carefully considered.

283 The earliest suggestion that the lake was becoming eutrophic came from Hecky and

284 Bugenyi (1992) who noted that the concentration of chlorophyll $a$ in bays along the lakeshore

285 had increased from 3-20 $\mu \mathrm{g}^{-1}$ in March 1961 to $13-71 \mu \mathrm{g} \mathrm{1^{-1 }}$ in May 1988. They wrote ‘...

286 the evidence for increased algal biomasses in Lake Victoria is worrisome, especially if it is

287 shown to be lakewide, as this eutrophication could lead to increased oxygen demand in the

288 lake's deep water and decrease the hypolimnetic volume habitable by fish during seasonal

289 stratification.' Data from 1990-91 confirmed that open waters, at least in the north of the lake,

290 had become eutrophic and the deeper waters seasonally deoxygenated (Hecky 1993; Hecky et

291 al. 1994).

292 It was known that deoxygenation occurred below the thermocline (Anon. 1952) and

293 the periodic deoxygenation of deeper waters in 1960-61 was described in more detail by

294 Talling (1966). The suggestion that this may have been an early manifestation of

295 eutrophication (van Zwieten et al. 2016) may be incorrect because it is well-known that even

296 oligotrophic tropical waters frequently develop anoxic hypolimnia owing to the rapid 
297

298

299

300

301

302

breakdown of organic matter at high temperatures (Ruttner 1953; Fryer 1972; Beadle 1981).

Fish kills, sometimes caused by anoxia, have been reported in many African lakes (Beadle 1981; Talling and Lemoalle 1998) and large fish mortalities were known to have occurred in Lake Victoria (Graham 1929). Details of most were not collected but significant kills were reported in 1927 and 1953 (Corbet 1961; Ochumba 1988) well before any obvious evidence of eutrophication.

Fish kills were identified as one of the consequences of eutrophication but those reported in the mid-1980s were attributed to stormy weather in the Kagera region of Tanzania in April-May 1984, algal blooms (undated), and an influx of acidic and deoxygenated swamp waters in Kenya after the 1984 drought (Ochumba 1988) which killed about 2,400 t of fish (Ochumba 1990). Mortality was caused by high levels of suspended detritus and algae following a storm, which clogged the gills of the fish, and to low dissolved oxygen, low $\mathrm{pH}$, and high concentrations of algae. Eutrophication was not specifically cited as a cause although high concentrations of blue-green algae were reported from the Kenyan sector of the lake in 1984-86 (Ochumba and Kibaara 1989).

One of the most striking features of eutrophication in Lake Victoria is its association with Nile perch and the haplochromine collapse. Prior to this event phosphorus concentrations in two shallow-water cores increased progressively from about 1960 (Hecky et al. 2010) but the most dramatic change occurred at the deep-water station V95-5MC (Figure 5a). Here the concentration increased from about $0.5 \mathrm{mg} \mathrm{g}^{-1}$ in 1940 to about to about $0.8 \mathrm{mg} \mathrm{g}^{-1}$ in the mid-1960s where it remained until 1984 . It then rose rapidly to $2.8 \mathrm{mg} \mathrm{g}^{-1}$ in 1995. This was attributed to prolonged anoxia liberating phosphorus deposited as organic matter, mostly from the algal blooms (Hecky et al. 2010). Significantly, this occurred in the mid-1980s after the haplochromines had collapsed in in Kenya and Uganda and were beginning to collapse in Tanzania. 
Other significant indicators of a change in the lake's status included the transition of

323 its dominant diatom flora from Aulacoseira to a long form of Nitzchia. This occurred rather

324 suddenly when the number of Aulacoseira valves in the sediment core decreased sharply

325 from about 1980 onwards (Figure 5b). A third indicator of change was a sharp decrease in the number of sub-fossil cladocerans in the sediments, which began around 1980 (Figure 5c). In both cases, these decreases occurred mostly after the haplochromines began to collapse, which suggests a link between the two events. These data strongly suggest that the Lake

329 Victoria ecosystem lost its resilience with the collapse of the haplochromines and shifted to a new state following the disruption of food chains and nutrient cycling that previously existed. Another interesting linkage appears to be the relationship between cladocerans and

The result was a simplified fish community, dominated by three species, Nile perch,

344 Nile tilapia and dagaa. Nile tilapia co-exists with Nile perch in its native habitat and presumably has innate defence mechanisms that allow it to do so, and it evidently benefitted 346 from the loss of the haplochromines by exploiting food resources previously unavailable to it 
347 (Njiru et al. 2004). Dagaa is a small, shoaling species with high relative fecundity (Table 5)

348 and presumably a high production/biomass ratio, as well as being a less favoured food item

349 for Nile perch (Figure 4). Another consequence of the haplochromine collapse was an

350 upsurge in the shrimp population, presumably because they were released from predation or

351 competition for food resources (Goudswaard et al. 2006).

352 It is difficult to imagine that the virtually instantaneous destruction of most of the 353 native fish biomass, estimated to be around 700,000 $\mathrm{t}$ in1969-71 (Kudhonhania and Cordone 354 1974), in Lake Victoria between 1981 and 1986 had little ecological impact. The complete 355 disruption of the complex food chains that previously existed in the lake must have changed 356 the nutrient recycling patterns in the lake and resulted in the algal blooms that developed in 357 the mid-1980s. Nevertheless, the idea that the destruction of the haplochromines could have caused these ecological changes still meets with resistance. For example, Witte et al. (2012) concluded that algal blooms were unlikely to have been caused by a top-down effect caused by the absence of grazing by phytoplankton-eating haplochromines. However, this work was based on the plankton consumption rates of two species from Lake George, Uganda, Haplochromis nigrippinis (endemic) and Nile tilapia, both of which were feeding almost exclusively on the blue-green algae Microcystis (Moriarty and Moriarty 1973). Applying their food consumption rates to the diverse pre-Nile perch haplochromine community feeding on the more diverse phytoplankton flora in Lake Victoria is questionable.

Ultimately, of course, it is not the loss of one trophic group that might have been responsible for algal blooms but the almost complete breakdown of all food chains in the lake. The notion that a single species could have such a profound effect on a very large and diverse ecosystem like Lake Victoria might be difficult to accept since diverse ecosystems are conventionally thought to be more stable and resistant. Natural food-web structures enhance ecosystem stability provided that consumer-resource interactions are relatively weak 
372 (McCann 2000; Ives and Carpenter 2009) and Lake Victoria must have had an extremely

373 wide variety of such consumer-resource interactions, both within the haplochromine

374 community and between them and other components of the ecosystem. In contrast, Nile perch

375 “...eats anything that moves..." (Hamblyn 1962) and its powerful consumer-resource

376 interactions broke down those previously existing in the lake. This in turn would have

377 disrupted nutrient cycling across the entire ecosystem. The extinction of fish can alter nutrient

378 recycling in tropical freshwaters (McIntyre et al. 2007) while biodiversity, especially trophic

379 complexity, plays an important role in the functioning of ecosystems (Duffy et al. 2007).

380 Nowhere was this demonstrated more clearly than in Lake Victoria where the loss of both

381 biodiversity and trophic complexity resulted in major ecological disruption. 2000, 2007, 2013; Kishe-Machumu et al. 2015a, 2015b) and there is general agreement that the demographic changes in Nile perch, brought about by intensive fishing, was a major factor. These are well illustrated by data from the Speke Gulf, Tanzania, where the catch rate 
87, fell to about $250 \mathrm{hg} \mathrm{hr}^{-1}$ in 1988 but then collapsed to $<100 \mathrm{~kg} \mathrm{hr}^{-1}$ in 1990 (Figure 7a). In contrast, the catch rate of fish $<35 \mathrm{~cm}$ rose steadily throughout the period and by 1990 the catch rates of the two groups were more or less equal.

Consequently, the Nile perch population is now dominated by fish $<25 \mathrm{~cm}$ in length

(Figure $7 \mathrm{~b})$ that feed primarily on shrimps (60-98\% frequency of occurrence). The larger fish $(25-45 \mathrm{~cm})$ preyed on haplochromines while fish $>45 \mathrm{~cm}$ increasingly fed on other Nile perch (Kishe-Machumu et al. 2008). This demographic change reduced predation pressure on the haplochromines and enabled some to recover, which was predicted by a bioenergetics model, which concluded that they would recover once Nile perch stocks were depleted by increased exploitation (Kitchell et al. 1997).

Many of the recovering species have exhibited novel adaptations to the new conditions in the lake which, predictably, took some time to become apparent. These include changes to their diet, habitat extensions such as inhabiting deeper or shallower waters than before, and morphological adaptations that enabled them to survive in the new conditions in the lake (Katunzi et al. 2003; Kishe-Machumu et al. 2008, 2015a, 2015b; Witte et al. 2008; van Rijssel et al. 2017). Witte et al. (2007) concluded that this differential recovery may have been caused by interspecific differences in ecology and adaptability that already existed within species before the lake changed, or simply by chance. It has also been suggested that the recovery may also have been facilitated by a more benign environment in the lake (KisheMachumu et al. 2015b; van Zweiten et al. 2016), indicated by the reduced stratification and anoxia noted in 2007-09 (Sitoki et al. 2010; Marshall et al. 2013).

The situation is fluid, however, and may be partly driven by changes in the biomass of Nile perch and shrimps. In acoustic surveys carried out from 1999-2001, Nile perch made up $54 \%$ of the biomass but that proportion was approximately halved in 2005-2010 (Table 6). The biomass of dagaa increased in 2005-2010 and again in 2014-2016 but haplochromine 
422 biomass fluctuated in relation to Nile perch. Thus, Nile perch fell by 52\% between 1999-2001

423 and 2005-2010 while haplochromines increased by $88 \%$, but in 2014-16 Nile perch increased

424 by $234 \%$ and haplochromines fell by $19 \%$. This suggests that Nile perch regulates

425 haplochromines to some extent, but its influence is lessened by the fact that most Nile perch

426 in 2014-16 were from 20-30 cm in length with haplochromines being a relatively small

427 proportion of their diet (Figure 4).

428 Finally, rapid evolutionary processes are the key to haplochromine diversity in the

429 African Great Lakes (Kaufman et al. 1997). If this is the case, could some of Lake Victoria's

430 surviving species have evolved the predator recognition and avoidance mechanisms that were

431 lacking when they first encountered Nile perch?

432

433 The bottom-up hypothesis

434 Recruitment depensation

435 The key to the bottom-up hypothesis is that the long delay between the introduction of

436 Nile perch and its population explosion resulted from a failure of recruitment caused by

437 haplochromine predation on Nile perch eggs or fry, or competition for food between them.

438 This notion was first proposed by Jackson (1971) although he provided no evidence to

439 support it. The idea gained traction from the Mwanza Gulf, where haplochromine populations

440 declined rapidly from about 1979 onwards while the Nile perch population only began to

441 explode in 1984 (Figure 3b). It was noted that haplochromines were initially abundant and

442 therefore Nile perch would not have been limited by a lack of food (Goudswaard et al.

443 2008). It was suggested that haplochromines may have inhibited recruitment of Nile perch,

444 which only ended when larger individuals migrated from the north and were able to prey on

445 haplochromines thus ending recruitment depensation. From this it was concluded that Nile

446 perch could only become established after some external factor depleted the haplochromines. 
447 After that, Nile perch would have reduced the numbers of piscivores and zooplanktivores in 448 the haplochromine population, further enhancing the survival of their own eggs and fry.

449 These conclusions led to the development of a 'recruitment depensation' model (van

450 de Wolfshaar et al. 2014) which suggested that once haplochromine mortality increased, Nile

451 perch were released from depensation, and so their numbers increased. The result was a

452 transition to a state where Nile perch dominated Lake Victoria and haplochromines no longer

453 controlled its recruitment. While this model seems to explain the apparent delay between the

454 introduction and expansion of the Nile perch population in Lake Victoria, it is not supported

455 by data.

456 Depensation is said to occur in a population when its per-capita growth rate increases

457 once its population density is reduced to low levels. In fisheries, it is usually associated with

458 stocks that have been reduced by over-fishing (Liermann and Hilborn 2001; Hutchings 2014).

459 The situation of Nile perch in Lake Victoria was, of course, quite different because it was not

460 a component of the lake's fish community. Its initial low population density was the result of

461 low introduction effort and not necessarily increased mortality. Its per-capita growth rate is

462 unknown but its population grew continuously from the time of its introduction (Tables 2, 3;

463 Figures 2, 3) and cannot be described as depensatory.

464 Could haplochromines control the recruitment or population growth of Nile perch?

465 Before addressing that question, it is useful to consider some biological attributes of Nile

466 perch. Its natural habitat, the rivers extending from Senegal to the Nile, vary both seasonally

467 and from year to year and are relatively harsh environments where most fish species

468 experience high mortality rates (Jackson 1961; Welcomme 1985; Lowe-McConnell 1987;

469 Lévêque 1997). The characteristics that enable it to survive in these situations, such as rapid

470 growth, high fecundity and a catholic diet, are commonly found in other successful invasive

471 species. It is also an effective predator capable of feeding on prey up to $38 \%$ of its length 
472 (Lévêque 1997) as well as small prey such as shrimps (maximum length c. 15 mm;

473 Goudswaard et al. 2006) or dagaa (maximum weight c. $2.0 \mathrm{~g}$; Douthwaite 1976). An

474 indication of its effectiveness as a predator - and a portent of things to come - was the

475 discovery of 35 haplochromines in the stomach of a 55-cm Nile perch (Gee 1969).

476 In their native habitats, such as Lake Albert, Nile perch spawn in shallow water and

477 their fry shelter amongst vegetation where their disruptive colouration would help them to

478 avoid predators (Gee 1964). In Lake Victoria they are known to spawn in similar situations

479 and ripe and ripe-running females were recorded throughout the year, suggesting the

480 possibility of continuous spawning although with a seasonal peak in November-December

481 (Ligtvoet and Mkumbo 1990). Its ability to spawn throughout the year and to breed in a variety of conditions was suggested as a reason for its success as an introduced species (Ogutu-Ohwayo 1988). fry some must have done so, but they may not have had any significant impact on Nile perch recruitment. The specialised egg-eating haplochromines, adapted to seizing relatively large and conspicuous eggs from mouth-brooding females (Witte and van Oijen 1995), were probably unable to adapt to those of Nile perch, which float but are small and transparent (Okedi 1970; Moreau 1982). These eggs are said to be planktonic (van Zwieten et al. 2016) in which case they might have been eaten by planktivores but being laid amongst vegetation close to the shore they are probably not a significant component of the zooplankton. Nile perch eggs are about $0.4 \mathrm{~mm}$ in diameter (Moreau 1982) and therefore larger than most rotifers, but zooplankton samples which included rotifers have not reported any Nile perch eggs or larvae (Mavuti and Litterick 1991; Waya and Mwambungu 2004; Ngupula et al. 
496 perch are most abundant in shallow water and move into deeper waters as they grow larger

497 (Katunzi et al. 2006).

498 Finally, the reproductive strategy of Nile perch may have minimised any impact of 499 haplochromine predation. At the time of the Nile perch explosion, females reached maturity 500 at about $70 \mathrm{~cm}$ (Ogutu-Ohwayo 1988) and their modal length was around $100 \mathrm{~cm}$ (Hughes 501 1992), which means they could produce from 1.1 to 3.1 million eggs per fish. Nile perch are 502 total spawners where all ova ripen at the same time and are shed in one batch (Lévêque 503 1997). This is the well-known reproductive strategy of predator swamping (Ims 1990), which ensures that a considerable number of eggs or larvae will survive even when mortality is high

505 (Furey et al. 2016). Thus, even if only $0.0001 \%$ of these eggs survived, each Nile perch

506 female would leave from 100-300 descendants in a single spawning (many more than a single 507 haplochromine could produce).

508 The proportion of piscivores in the pre-Nile perch haplochromine community is 509 unknown but scattered data suggest they may not have been numerous. In 1964, nine 510 Haplochromis species were collected in the Bugungu Lagoon, Uganda, of which five were 511 piscivores and made up $6.6 \%$ of the total catch (Welcomme 1965). This semi-enclosed 512 lagoon may not, however, represent the lake as a whole and a possibly more representative 513 sample of 47,975 haplochromines, collected in Uganda in 1965, mostly by poisoning, 514 included only 291 'predators' or $0.61 \%$ of the total (Hamblyn 1966). An estimate from the 515 Mwanza Gulf in 1978 found that they made up 1.1\% of the samples in 1978 (Witte et al. 516 2007a) but only $0.26 \%$ of samples in $1979-80$ (Witte et al. 1995).

517 This is much less than the predation pressure Nile perch are exposed to in their native 518 range. In Lake Albert, for instance, the top piscivores Nile perch and Hydrocynus spp. made 519 up around $25-35 \%$ of the catch in seine and gill nets, while omnivores capable of preying on 520 juvenile Nile perch such as Bagrus bajad made up to $15 \%$ of the 51 -mm seine catch (Ogutu- 
521 Ohwayo 1995). Elsewhere in the Nile system they co-exist alongside a diverse array of

522 piscivores and omnivores (Abdel-Latif 1984; Hickley and Bailey 1987) and their fry must

523 possess innate predator recognition and avoidance mechanisms that enable them to survive in

524 these situations. These would have helped them to avoid haplochromine predation in Lake

525 Victoria.

526 In any case, the window of opportunity for haplochromines to prey on Nile perch

527 would have been very small since they grow rapidly, reaching $5 \mathrm{~cm}$ in about 2 months

528 (Hughes 1992). Piscivorous haplochromines, mostly 10-16 cm in length (Witte and van Oijen 529 1995), would have been unable to feed on them at this size. There is therefore little evidence

530 to support the notion that haplochromines significantly influenced Nile perch recruitment and

531 population growth. The recruitment depensation hypothesis is further undermined by the fact

532 that the Nile perch population grew continuously throughout the expansion phase.

Impact of fishing

535 Even without recruitment depensation, the "bottom-up" hypothesis still requires an 536 external influence to bring about a haplochromine decline prior to the Nile perch explosion.

537 The intensive industrial trawl fishery in the Mwanza Gulf clearly depleted haplochromine 538 stocks (Figure $3 b$ ) but the situation here was not representative of the lake as a whole. It has 539 also been argued that fishing selectively depleted the population of haplochromine piscivores, 540 so improving the survival of Nile perch fry. There is no evidence to support this view and 541 notions of a differential decline need to be considered more closely.

542 In the Mwanza Gulf, the total number of haplochromines caught in 10-minute bottom 543 trawls decreased by $94 \%$ between $1979-80$ and $1985-86$, with the least numerous groups 544 apparently declining most rapidly (Table 7). If the values are standardised, with the highest 545 value equal to 1.0, and plotted against time then both the most numerous group, the 
546 detritivore/phytoplankivores, and the piscivores declined at the same rate (slope $b=-0.35$ in

547 both). This suggests that piscivores were not selectively removed by fishing and their catch

548 rate would have fallen to 0.06 per haul or effectively zero by $1985-86$. Moreover, the $1979-80$

549 data are derived from a total of 32 hauls, while there were only 8 hauls in $1985-86$, and the

550 likelihood of catching scarce individuals will diminish when sampling effort is low.

551 There is no evidence from anywhere else in the lake that haplochromines decreased

552 significantly before the Nile perch explosion (Tables 2 and 3). Small-meshed gillnets and

553 beach seines were being used around the lake to catch haplochromines and the juveniles of

554 larger species (Marten 1979b). Mosquito nets, used mainly to catch dagaa but also small

555 haplochromines and juvenile Nile perch, were becoming increasingly common and believed

556 to have damaging effects on fish stocks (Asila 1997). It is not obvious, however, that these

557 gears depleted either haplochromines or Nile perch. Trawl surveys in the heavily-fished

558 Nyanza Gulf indicated a small (6\%) decline in haplochromine biomass but a very large

559 increase (169\%) in Nile perch between 1969-70 and 1977 (Table 8).

560

561

Eutrophication

562 Widespread hypoxia caused by eutrophication was said to be primarily responsible for

563 the loss in haplochromine abundance and diversity (Kolding et al. 2008; Hecky et al. 2010;

564 van Zwieten et al. 2016). The question that needs to be asked in connection with

565 eutrophication is: if conditions in the lake deteriorated to the point where almost all native

566 species, including air-breathing species, such as the catfish Clarias gariepinus and lungfish

567 Protopterus aethiopicus, succumbed to hypoxia then how did Nile perch, Nile tilapia and

568 dagaa survive and flourish? This question is especially pertinent in view of the fact that

569 haplochromines are significantly more tolerant of hypoxia than Nile perch, while dagaa is the

570 least tolerant species (Witte et al. 2005). 
It was suggested that hypoxic deep waters $(>40 \mathrm{~m})$, where Nile perch could not

572 survive, provided a refuge for haplochromines but as anoxia increased they were forced into

573 shallow water where they were exposed to the predator (Kaufman and Ochumba 1993; Hecky

574 et al. 1994; Bundy and Pitcher 1995; Ochumba 1995). This idea is countered by evidence

575 that Nile perch penetrated deep water from the beginning of its population explosion. For,

576 example, trawl samples from the Emin Pasha Gulf, Tanzania, in June 1985 (just before the

577 haplochromine collapse) revealed that Nile perch were most numerous at depths of 20-50 m

578 while haplochromines were mostly found from 0-20 m (Figure 8). Similar findings were

579 reported from the Mwanza Gulf (Goudswaard and Ligtvoet 1987). Furthermore, Nile perch

580 are known to enter the hypoxic layer regularly and can probably forage there for short periods

581 (Wanink et al. 2001).

Another consequence of eutrophication was the fish kills that occurred in the mid-

1980s, but these had little impact on the haplochromines since they had already collapsed.

The 1984-85 kills in Kenya involved only Nile perch and Nile tilapia (Ochumba 1990). There

were no kills attributable to hypoxia in the Mwanza Gulf between 1977 and 1987, but after

the haplochromine collapse several mass mortalities of Nile perch occurred, with a

particularly large one in April 1988 (Wanink et al. 2001; Witte et al. 2005).

Increased turbidity resulting from dense algal blooms interferes with mate choice in haplochromines since females select males on the basis of colouration. There is evidence that poor visibility caused by these algal blooms may have affected their reproduction resulting in hybridisation (Seehausen et al. 1997; Witte et al. 2007a) and even breeding failure in some species (Witte et al. 2000). It was further suggested that decreased prey selectivity resulting

593 from low visibility would lead to increased interspecific competition as a result of loss of 594 feeding specialization. This would have a negative impact on species coexistence, especially 595 in those species that are visual predators of highly evasive prey (Seehausen et al., 2003). 
596

597

598

599

600

601

602

603

604

605

606

607

608

609

610

611

612

613

614

615

616

617

618

619

620

The difficulty here is that these findings post-date the haplochromine collapse and it remains unclear how much turbidity contributed to this event, especially as average inshore transparency did not change significantly between 1927 and 2000-01 and much less than in offshore waters (Table 9). The decrease in inshore transparency between 2000-01 and 200609 could reflect increasing silt loads from degraded land in the basin, estimated to be about $6.5 \times 10^{6}$ t year $^{-1}$ (Mnyanga et al. 2005). Transparency is, of course, highly variable and can be affected by differences in sediment and phytoplankton concentrations, which can also affect spectral attenuation as well. Thus, transparency decreased significantly in the Mwanza Gulf (Witte et al 2005), possibly because of an increase in sediment loading since the gulf is at the mouth of a river and the surrounding catchment is heavily degraded (Mnyanga et al. 2005). If turbidity was affecting haplochromine reproduction it would surely have been localised and any impacts on the population would most likely have been progressive and cumulative. It is difficult to see how this could have contributed to the catastrophic collapse of the haplochromines.

Finally, van Zwieten et al. (2016) suggest that long-term eutrophication could have contributed to the haplochromine decline by reducing resources specifically available to them, but not to Nile perch. Their argument centred around changes to the zooplankton, specifically the reduction of cladocerans, which was said to have changed the availability and quality of food at the base of the haplochromine food web. This was thought to have depleted the food resources available to juvenile and zooplanktivorous haplochromines. It is unclear why changes in the plankton should have deprived the haplochromines of a major food source while at the same time allowing planktivorous Nile perch fry and dagaa to flourish. A four-fold increase lake fly abundance, including the zooplanktivorous dipteran Chaoborus, is mentioned in van Zwieten et al. (2016) although they did not specifically identify them as a food source for either Nile perch, haplochromines or dagaa, or directly 
621 implicate them as a cause of the plankton decline. There are few quantitative estimates of

622 dipteran abundance in Lake Victoria, but those that are available do not indicate a significant 623 increase at the time of the Nile perch explosion (Table 10). Benthic invertebrate population 624 can vary extensively, depending on the nature of the substrate, aquatic vegetation, and so on, 625 and they remain as a major gap in the ecological data from Lake Victoria.

626

\section{The climatic event}

The second external factor that might support the bottom-up hypothesis is the climatic event that lasted from 1976-1983 (van Zwieten et al. 2016). The data in this paper come from a single locality on the western shore of the lake and may not reflect the full complexity of the lake's climate, which varies from north to south, while it also generates its own climate (Song et al. 2004; Anyah et al. 2006).

During this period air temperature and wind speeds were well below average while relative humidity was above average. It was inferred that this prolonged period of low wind stress led to strengthened stratification in the lake (Kolding et al. 2008; MacIntyre 2013; MacIntyre et al. 2014). This was thought to have limited vertical mixing, resulting in a larger anoxic volume in the deeper waters and substantially increasing the availability of phosphorus liberated from internal sedimentary sources. The resultant algal blooms together with anoxia were then thought to have contributed to the demise of the haplochromines. This event was said to have been exacerbated by an El Niño event in 1982-83, which led to increased stratification.

There is no direct evidence to support this contention owing to the lack of limnological data from Lake Victoria between the 1960s (Talling 1966) and the 1990s (Hecky 1993; Muggide 1993; Hecky et al. 1994). Conclusions based on data from the 1990s, after the major changes in the lake had already occurred, entail the risk of projecting existing conditions back into the past. It was suggested that there had been a steady decline in 
647 offshore oxygen concentrations from about 1960 onwards and that in the 1970s and 1980s

648 waters deeper than 70 m experienced severe anoxia (Hecky et al 1994; Verschuren et al.

649 2002). This was inferred from a shift in the dominant chironomid genera found in the deep-

650 water sediment core V95-5MC (Verschuren et al. 2002). While this reflects the conditions in

651 the sediments and at the sediment-water interface, the explanation may be less simple than

652 this since Chironomus can be abundant in oxygenated water. For instance, it was common in

653 Ekunu Bay, Uganda, in water $10 \mathrm{~m}$ deep where oxygen saturation ranged from $60-80 \%$, and

654 although samples were not fully quantitative the average and maximum densities were

655 approximately 800 and $1000 \mathrm{~m}^{-2}$ respectively (MacDonald 1956). It was also abundant and

656 the only genus in newly-inundated drawdown zones, rich in organic matter but well-

657 oxygenated, of two Zimbabwean reservoirs, one oligotrophic and the other eutrophic

658 (McLachlan 1970; Marshall 1978).

The size-based model

The size-spectrum model proposed by van Zwieten et al. (2016) addressed four specific questions related to the depensation hypothesis, namely (1) was stable co-existence between haplochromines and Nile perch possible and if so, then was it likely that (2) fishing, (3) predation or (4) limnological conditions weakened depensation sufficiently to initiate the Nile perch explosion. Questions 2, 3 and 4 seem to be redundant since there is no evidence that haplochromines exerted any depensatory effects on Nile perch. Indeed, the fact that Nile perch numbers grew throughout the establishment phase confirms this, while the biological characteristics of Nile perch suggest that they would be able to resist haplochromine predation. 
672 expansion. If this means that populations remained more or less the same, varying within

673 narrow limits, during this period then it did not exist in Lake Victoria. In fact, the Nile perch

674 population was expanding quite rapidly in the northern waters of the lake from the time of its

675 introduction. As mentioned, the early warning signal of increased Nile perch recruitment was

676 evidently overlooked even though this fish was becoming increasingly important in the

677 fisheries (Achieng 1990; Acere 1998; Asila 1997). The extent of this oversight is revealed by

678 the statement in van Zwieten et al. (2016) who wrote '... large numbers of Nile perch recruits

679 only appeared in Tanzania in the second half of 1985 and in Uganda perhaps as late as 1989.'

680 While this may be true for Tanzania it is highly improbable for Uganda where the cumulative

681 Nile perch catch between 1980 and 1988 exceeded 600,000 t (Ogutu-Ohwayo 1995) and

682 could not have been achieved without massive recruitment.

683 The hypothesis proposed by van Zwieten at al. (2016) is that a switch from

684 haplochromine dominance to Nile perch depended on size-related differences in mortality

685 caused by predation on eggs and juveniles. They attributed the relatively stable co-existence

686 between adult Nile perch and haplochromines over two decades to intra-guild size-dependent

687 predation. This presumably refers to predation of Nile perch eggs and fry by haplochromines,

688 suggested by the size difference between haplochromine fry at the time they leave the

689 female's mouth and Nile perch hatchlings. This is illustrated in their Figure 2, which shows a

690 relatively advanced haplochromine juvenile about $13 \mathrm{~mm}$ in length and a Nile perch larva

691 one-tenth its size (about $1.5 \mathrm{~mm}$ ). This figure implies that the seemingly helpless Nile perch

692 would be easy prey for the haplochromine but this is misleading. It takes no account of the

693 fecundity and breeding behaviour of Nile perch or predator avoidance mechanisms of the fry,

694 which include disruptive colouration that varies according to habitat (Nyboer et al. 2014).

695 The maternal mouth-brooding strategy of haplochromines can protect their juveniles

696 from predation, allowing them to be released at a relatively advanced stage of development. 
697 But this will be a successful strategy only if they are able to defend their broods and minimise

698 losses from predators. Once they were exposed to Nile perch this advantage was lost because

699 a mouth-brooding female haplochromine swallowed whole by a Nile perch leaves no

700 descendants, and will never spawn again.

701 The final question was whether or not limnological changes weakened depensation

702 and contributed to the Nile perch upsurge. This too, has already been discussed and it is

703 sufficient to comment that if there was no depensation then limnological changes could not

704 have weakened it. More pertinently, would the haplochromines have collapsed so catastrophically if Nile perch had not been present? It seems improbable, because although the lake might have changed progressively it is likely that haplochromines would have adapted, as some have already done (Katunzi et al. 2003; Kishe-Machumu et al. 2008, 2015a, 2015b; Witte et al. 2008; van Rijssel et al. 2017).

Finally, some of the conclusions drawn from this model do not reflect reality. One of these is that the continued expansion of Nile perch into deep offshore waters, as well as its continued increase in relative biomass, indicates that the colonisation of Lake Victoria by

712 Nile perch is not yet complete (van Zweiten et al. 2016). This is a puzzling conclusion since Nile perch have been in the lake for 60 years and its population exploded 35 years ago. What parts of the lake remain to be colonised? In fact, Nile perch occur throughout, although they tend to be more numerous in inshore waters (Getabu et al. 2003; Everson et al. 2013; TaabuMunyaho et al. 2014) and at most depths, with numbers declining at depths $>50 \mathrm{~m}$ (Okaronon and Ntiba 2000; Mkumbo et al. 2005; Taabu-Munyaho et al. 2013; Table 11). The biomass of Nile perch varies (Table 6) but there is no reason to suppose that it is continuously increasing.

Two recent papers discussed theoretical models of the Nile perch population growth 721 in Lake Victoria. The first (van de Wolfshaar 2013) proposed recruitment depensation as a 
722

723

724

725

726

727

728

729

730

731

732

733

734

735

736

737

738

739

740

741

742

743

744

745

746

mechanism that delayed the explosive growth of this species. The second (Downing et al. 2014) modelled various options, including depensation and predation, and concluded that the timing of the Nile perch explosion could be explained by simple logistic growth. However, they argued that data on the introduction and invasion of Nile perch in Lake Victoria were too few and scattered to produce any insight into the mechanisms or biology behind the invasion process. While there is some truth in this conclusion, there are sufficient data to explain the growth of Nile perch in Lake Victoria and confirm the view that logistic growth alone can explain can explain the Nile perch explosion.

The top-down hypothesis is straightforward, requires few assumptions and is essentially a simple predator-prey relationship that conforms to the law of parsimony. It also gains credibility from the fact that similar impacts of introduced predators are well known in both terrestrial and aquatic ecosystems (Pitt and Wilmer 2007). Whole-lake ecosystem disruption following the introduction of a non-native predator was first documented over 40 years ago (Zaret and Paine 1973), and many cases have since been reported (e.g. Eby et al. 2006; Pelicice and Agostinho 2009; Cucherousset and Olden 2011; Atkinson and Domske 2015). Lake Victoria is yet another example, albeit on a larger scale than many others. The chronology of events also supports the view that the collapse of the haplochromines preceded and may have caused the cascading sequence that led to accelerated eutrophication. It confirms the chronology published in Verschuren et al. (2002) which indicated that the Nile perch explosion, which led to the haplochromine collapse, began in about 1980 and massive algal blooms followed in about 1985.

Events that followed the introduction of Nile perch into other lakes also support this hypothesis. It devastated haplochromine populations in lakes Nabugabo and Kyoga (Uganda) although there has been some recovery in both after intensive fishing of Nile perch (Chapman et al. 2003; Paterson and Chapman 2009; Mbabazi et al. 2004; Ogutu-Ohwayo et al. 2013). 
747 Some satellite lakes of Lake Kyoga, inaccessible to Nile perch, still retain their

748 haplochromine fauna, further confirming the impact of this predator. Aquatic vegetation

749 played an important role in both of these lakes by sheltering haplochromines and the

750 importance of cover was emphasised in Lake Victoria by the fact that rock-dwelling species

751 were less severely reduced by Nile perch than those living in open waters (Witte et al. 2007).

752 The bottom-up hypothesis founders on the lack of direct evidence and relies heavily

753 on assumptions that are not supported by data. An examination of the biological aspects of

754 Nile perch and haplochromines suggests that its cornerstone, recruit depensation, has been

755 overstated and predation by haplochromines may have had little impact on Nile perch. The

756 possibility that cannibalism may have been the major cause of mortality in Nile perch cannot

757 be discounted; it became important towards the end of the expansion phase but could have

758 occurred during the establishment phase as well.

759 So far, the most important drivers of change in the fish stocks of Lake Victoria are

760 Nile perch and fishing; the former causing native species to decrease and the latter by enabling some recovery through the removal of Nile perch. No one would disagree that eutrophication is an important ecological driver in the lake but the view that it is an unrelenting and continuous process, and the major long-term threat to the fisheries in Lake Victoria (Kolding et al. 2008) has yet to be substantiated. Its most important impact so far is a dramatic increase in fisheries productivity with the annual catch now around one million tonnes, a ten-fold increase on pre-1980 catches (Mkumbo and Marshall 2015). not there could be a 'stable co-existence' between haplochromines and Nile perch. Given the

769 changes that have occurred in the lake it seems unlikely. Such a co-existence seemed to

770 prevail from the time Nile perch were introduced until the time its population exploded some

77120 years later, but this was illusory. Instead, Nile perch was steadily increasing until reaching 
772 a point where the haplochromine population lost its resilience and collapsed. For the next 20

773 years the lake was essentially a Nile perch-dominated lake, with only dagaa and Nile tilapia

774 surviving in any numbers. The lake now seems to be entering a new phase, with

775 haplochromines beginning to recover and Nile perch possibly declining. How long this will

776 last and what changes may occur in future remains to be seen.

777 Management plans for the lake (e.g. Anon. 2009, 2013) call for a 'recovery' of the

778 Nile perch stocks, i.e. increasing the number of more profitable large fish. If this objective

779 were to be achieved the result could be another haplochromine collapse and aggravated

780 eutrophication. Little-noticed, but potentially very important, is the growing

781 commercialisation of the shrimp stocks, which are caught both for poultry-feed and export to

782 neighbouring countries (Budeba and Cowx 2007). If shrimps were severely depleted by

783 fishing (or through competition from the recovering haplochromines) the survival of young

784 Nile perch could be severely compromised, thus negating any managements measures

785 designed to 'recover' the Nile perch fishery.

786 The model presented by van Zwieten et al. (2016, p. 637) concluded with the

787 statement that 'Haplochromines and Lates species co-exist in other African Great Lakes as

788 well, and so the Nile perch outburst in Lake Victoria, possibly a consequence of the

789 haplochromine demise, was perhaps an anomaly.' This view is disingenuous and misleading.

790 Nile perch do indeed occur naturally in lakes Albert and Turkana but their fish faunas are

791 Nilotic and co-evolved with it. Significantly, both lakes lack the diverse and highly

792 specialised haplochromine species-flocks that evolved in isolation in the other Great Lakes.

793 Lake Tanganyika is the only one that supports both a haplochromine species-flock (with

794 many fewer species than lakes Victoria and Malawi) as well as four relatively specialised

795 endemic Lates spp. (Coulter 1991). These two groups share a long evolutionary history,

796 perhaps extending over 9-12 million years (Cohen et al. 1993). 
The situation in Lake Victoria is not an anomaly but is the entirely predictable consequence of introducing a voracious top predator into an ecosystem where no such species had ever existed. Nile perch has a high reproductive potential, can withstand heavy mortality, and faced no competition in the lake. Furthermore, its main prey species were naïve and had never been exposed to such a predator. It was introduced into the lake specifically to utilise the haplochromines (Anderson 1961) which it did with remarkable efficiency. The potential impacts of introduced species were known at the time of the introduction (Elton 1958) but the extent and severity of its consequences were evidently unforeseen. The data and sequence of events presented here clearly indicate that Nile perch was the cause, and not the consequence, of the haplochromine decline and was thus the principal agent of change in Lake Victoria.

\section{Acknowledgements}

These ideas have benefitted greatly from discussions with scientists in East Africa during the time I spent at the Lake Victoria Fisheries Organisation, although any errors are mine alone. I am grateful to Maditaba Meltaf (Margaret Smith Library, Grahamstown, South Africa) and Alice Endra (NaFFIRI, Jinja) for their ready assistance in obtaining literature for me. I also acknowledge the comments from two anonymous referees, which led to many changes in the manuscript.

\section{References}

Abdel-Latif. A.-F. 1984. Lake Nasser. In Status of African reservoir fisheries. Edited by J.M. Kapetsky and T. Petr. CIFA Tech. Pap. 10: 193-246. Rome, FAO.

Acere, T.O. 1984. Observations on the biology, age, growth, maturity and sexuality of Nile perch (Lates niloticus), and the growth of its fishery in the northern waters of Lake Victoria. In CIFA, Report of the Third Session of the Sub-Committee for the 
822

823

824

825

826

827

828

829

830

831

832

833

834

835

836

837

838

839

840

841

842

843

844

845

Development and Management of the Fisheries of Lake Victoria, 4-5 October 1984, Jinja, Uganda. FAO Fish, Rep. (335): 42-61.

Acere, T.O. 1988. Recent trends in the fisheries of Lake Victoria (Uganda northern part). In Committee for Inland Fisheries of Africa, 1988 Report of the fourth session of the SubCommittee for the development and management of the fisheries of Lake Victoria. Kisumu, Kenya, 6-10 April 1987. FAO Fish. Rep. (388): 36-45.

Achieng, A.P. 1990. The impact of the introduction of Nile perch, Lates niloticus (L.) on the fisheries of Lake Victoria. J. Fish Biol. 37 (Suppl. A): 17-23. doi: 10.1111/j.10958649.1990.tb05016.x

Anderson, A.M. 1961. Further observations concerning the proposed introduction of Nile perch into Lake Victoria. E. Afr. Agric. For. J. 26: 195-201.

Anon. 1952. Hydrology and algology. In EAFFRO Ann. Rep., 1951: 5-8. East African Freshwater Fisheries Research Organisation, Jinja, Uganda.

Anon. 1964. The Nile perch in Lake Victoria. In EAFFRO Ann. Rep., 1962-63: 7. East African Freshwater Fisheries Research Organisation, Jinja, Uganda.

Anon. 1966. Nile perch investigations. In EAFFRO Ann. Rep., 1965: 9-10. East African Freshwater Fisheries Research Organisation, Jinja, Uganda.

Anon. 2009. Nile perch fishery management plan for Lake Victoria. Lake Victoria Fisheries Organization, Jinja, Uganda, 42 pp.

Anon. 2013. Revised Nile perch Fishery Management Plan for Lake Victoria. SOFRECO, for ACP Fish II, European Union, 53 pp. Available from http://acpfish2eu.org/uploads/projects/id237/I1698\%20-\%20EA-1.2-B3\%20\%20Final $\% 20$ Technical $\% 20$ Report $\% 20$ Revised $\% 20131127 \% 20$ STR.pdf (accessed 3 February 2017). 
846

847

848

849

850

851

852

853

854

855

856

857

858

859

860

861

862

863

864

865

866

867

868

869

870

Anyah, R.O., Semazzi, F.H.M. and Xie, L. 2006. Simulated physical mechanisms associated with climate variability over Lake Victoria Basin in East Africa. Month. Weather Rev. 134:3588-3609. doi: 10.1175/MWR3266.1

Asila, A. 1997. Changes in the fisheries and fish stocks after the spread of Nile perch (Lates niloticus) in the Kenyan waters of Lake Victoria. In African Fisheries, Aquaculture and Environment. Edited by K. Remane. Fishing News Books, Oxford: pp. 318-325.

Atkinson, J.F. and Domske, H.M. 2015. Great Lakes under stress: invasive species as agents of ecosystem change. Lessons in Conservation, No 5 (Water Issue): 17-31. American Museum of Natural History, New York.

Barel, C.D.N., Dorit, R., Greenwood P.H., Fryer, G., Hughes, N., Jackson, P.B.N., Kawanabe, H., Lowe-McConnell, R.L., Nagoshi, M., Ribbink, A.J., Trewavas, E., Witte, F. and Yamaoka, K. 1985. Destruction of fisheries in Africa's lakes. Nature 315(6014): 19-20. doi:10.1038/315019a0

Beadle, L.C. 1981. The inland waters of tropical Africa. An introduction to tropical limnology, $2^{\text {nd }}$ edn. Longman, London.

Budeba, Y.L. and Cowx, I.G. 2007. Contribution of Caridina nilotica (Roux) in the dagaa fishery in Lake Victoria, Tanzania. Aquat. Ecosys. Health Manage. 10(4): 381 - 391. doi: $10.1080 / 14634980701703942$

Bundy, A. and Pitcher, T.J. 1995. An analysis of species changes in Lake Victoria: did Nile perch act alone? In The impact of species changes in African lakes. Edited by T.J. Pitcher and P.J.B. Hart. Chapman and Hall, London: pp. 111-135.

Bwathondi, P.O.J. 1990. The state of Lake Victoria fisheries, Tanzanian Sector. In Report of the Fifth Session of the Sub-Committee for the Development and Management of the Fisheries in Lake Victoria, 12-14 September 1989, Mwanza, Tanzania. FAO Fish. Rep. (430): 24-34. 
871 Chapman, L.J., Chapman, C.A., Schofield, P.J., Olowo, J.P., Kaufman, L., Seehausen O. and 872 Ogutu-Ohwayo, R. 2003. Fish faunal resurgence in Lake Nabugabo, East Africa. Cons. 873 Biol. 17(2): 500-511. doi: 10.1046/j.1523-1739.2003.01519.x

874 Cohen, A.S., Soreghan, M.J. and Scholz, C.A. 1993. Estimating the age of formation of 875 lakes: an example from Lake Tanganyika, East African rift system. Geology 21(6): 511$876 \quad$ 514. doi: $10.1130 / 0091-7613(1993) 021<0511: E T A O F O>2.3 . C O$

877 Corbet, P.S. 1961. The food of non-cichlid fishes in the Lake Victoria basin, with remarks on 878 their evolution and adaptation to lacustrine conditions. Proc. Zool. Soc. Lond.136(1):1879 101. doi: 10.1111/j.1469-7998.1961.tb06080.x

880 Coulter, G.W., ed. 1991. Lake Tanganyika and its life. Natural History Museum and Oxford 881 University Press, London.

882 Cucherousset, J and Olden, J.T. 2011. Ecological impacts of non-native freshwater fishes. $883 \quad$ Fisheries 36(5): 215-230.

884 Douthwaite, R.J. 1976. Fishing techniques and foods of the Pied Kingfisher on Lake Victoria 885 in Uganda. Ostrich 47(4): 153-160. http://dx.doi.org/10.1080/00306525.1976.9639555 886 Downing, A.S, Galic, N., Goudswaard, K.P.C., van Nes, E.H., Scheffer, M., Witte, F. and 887 Mooij, W.M. 2014. Was Lates late? A null model for the Nile perch boom in Lake 888 Victoria. PLoS ONE 8(10): e76847. doi:10.1371/journal.pone.0076847 889 Duffy, J.E., Cardinale, B.J., France, K.E., McIntyre, P.B., Thébault, E. and Loreau, M. 2007. 890 The functional role of biodiversity in ecosystems: incorporating trophic complexity. 891 Ecol. Lett. 10(6): 522-538. doi: 10.1111/j.1461-0248.2007.01037.x 892 Dumont, H.J. 1986. The Tanganyika sardine in Lake Kivu: another ecodisaster for Africa? 893 Environ. Conserv. 13(2), 143-148. doi.org/10.1017/S0376892900036742 
894

895

896

897

898

899

900

901

902

903

904

905

906

907

908

909

910

911

912

913

914

915

916

917

Duponchelle, F., Paradis, E., Ribbink, A.J. and Turner, G.F. 2008. Parallel life history evolution in mouthbrooding cichlids from the African Great Lakes. Proc. Nat. Acad. Sci., USA 105(40):15475-15480. www.pnas.org_cgi_doi_10.1073_pnas.0802343105

Eby, L.A., Roach, W.J., Crowder, L.B. and Stanford, J.A. 2006. Effects of stocking-up freshwater food webs. Trends Ecol. Evol. 21(10): 576-584. doi: http://dx.doi.org/10.1016/j.tree.2006.06.016

Elton, C. 1958. The ecology of invasions by animals and plants. Methuen, London.

Everson, I., Taabu-Munyaho, A. and Kayanda, R. 2013. Acoustic estimates of commercial fish species in Lake Victoria: moving towards ecosystem-based fisheries management. Fish. Res. 139(1): 65- 75. https://doi.org/10.1016/j.fishres.2012.09.019

Fryer, G. 1972. Conservation of the great lakes of East Africa: a lesson and a warning. Biol. Conserv. 4(4): 256-262. doi: http://dx.doi.org/10.1016/0006-3207(72)90121-8

Fryer, G. 1973a. Hopeful empiricism versus the scientific method: the Nile perch controversy revived. Biol. Conserv. 5:222-223. doi: https://doi.org/10.1016/0006-3207(73)90020-7

Fryer, G. 1973b. The Lake Victoria fisheries: some facts and fallacies. Biol. Conserv. 5(4): 304-308. https://doi.org/10.1016/0006-3207(73)90165-1

Furey, N.B., Hinch, S.G., Bass, A.L., Middleton, C.T., Minke-Martin, V. and Lotto, A.G. 2016. Predator swamping reduces predation risk during nocturnal migration of juvenile salmon in a high-mortality landscape. J. Anim. Ecol. 85(4): 948-959. doi: 10.1111/13652656.12528

Gee, J.M. 1964. Nile perch investigations. In EAFFRO Ann. Rep., 1962-63: 14-22. East African Freshwater Fisheries Research Organisation, Jinja, Uganda.

Gee, J.M. 1965. The spread of Nile perch Lates niloticus (L.) in East Africa, with comparative biological notes. J. Appl. Ecol. 2(2):407-408. doi: 10.2307/2401489 
Gee, J.M. 1969. A comparison of certain aspects of the biology of Lates niloticus (Linne) in some East African Lakes. Rev. Zool. Bot. Afr. 80: 244-262.

Gee, J.M. and Gilbert, M.P. 1967. Experimental trawling operations on Lake Victoria. In EAFFRO Ann. Rep., 1966: 33-46. East African Freshwater Fisheries Research Organisation, Jinja, Uganda.

Getabu, A., Tumwebaze R. and MacLennan, D.N. 2003. Spatial distribution and temporal changes in the fish populations of Lake Victoria. Aquat. Living Resour. 16(3):159-165. https://doi.org/10.1016/S0990-7440(03)00008-1

Goldschmidt, T., Witte, F. and Wanink, J. 1993. Cascading effects of the introduced Nile perch on the detritivorous/planktivorous species in the sublittoral areas of Lake Victoria. Cons. Biol. 7(3): 687-700. doi: 10.1046/j.1523-1739.1993.07030686.x

Gophen, M., Ochumba, P.B.O. and Kaufman, L.S. 1995. Some aspects of perturbation in the structure and biodiversity of the ecosystem of Lake Victoria (East Africa). Aquat. Living Resour. 8(1): 27-41. doi: http://dx.doi.org/10.1051/alr:1995003

Goudswaard, P.C. and Ligtvoet, W. 1988. Recent developments in the fishery for haplochromines (Pisces: Cichlidae) and the Nile perch, Lates niloticus (L.) (Pisces: Centropomidae) in Lake Victoria. In Report of the 4th Session of the Sub-committee for the Development and Management of the Fisheries in Lake Victoria. FAO Fish. Rep. (388): pp. 101-112.

Goudswaard, P.C., Witte, F. and Katunzi, E.F.B. 2002. The tilapia fish stock of Lake Victoria before and after the Nile perch upsurge. J. Fish Biol. 60(4):838-858. doi: 10.1111/j.10958649.2002.tb02413.x

Goudswaard P.C., Witte, F. and Wanink, J.H. 2006. The shrimp Caridina nilotica in Lake Victoria (East Africa), before and after the Nile perch increase. Hydrobiologia 563(1): 31-44. doi: 10.1007/s10750-005-1385-9 
Goudswaard, P.C., Witte, F. and Katunzi, E.F.B. 2008. The invasion of an introduced predator, Nile perch (Lates niloticus) in Lake Victoria (East Africa): chronology and causes. Environ. Biol. Fish. 81(2): 127-139. doi: 10.1007/s10641-006-9180-7

Graham, M. 1929. The Victoria Nyanza and its fisheries. A report on the fishing survey of Lake Victoria, 1927-1928. London, Crown Agents for the Colonies: 255 pp.

Hamblyn, E.L. 1962. Nile perch investigations. In EAFFRO Ann. Rep. 1961: 23-28. East African Freshwater Fisheries Research Organisation, Jinja, Uganda, pp. 23-28.

Hamblyn, E.L. 1966. A note on the inshore fish population of Napoleon Gulf (Lake Victoria). In EAFFRO Ann. Rep., 1965: 23-25. East African Freshwater Fisheries Research Organisation, Jinja, Uganda.

Hecky, R.E. 1993. The eutrophication of Lake Victoria. Verh. Internat. Verein. Limnol. 25: $39-48$.

Hecky, R.E. and Bugenyi, F.W.B. 1992. Hydrology and chemistry of the African great lakes and water quality issues: problems and solutions. Mitt. Internat. Verein. Limnol.23: 4554.

Hecky, R.E., Bugenyi, F.W.B., Ochumba, P., Muggide, R., Gophen, M. and Kaufman L. 1994. Deoxygenation of the deep water of Lake Victoria, East Africa. Limnol. Oceanogr. 39(6): 1476-1481. doi: 10.4319/1o.1994.39.6.1476

Hecky, R.E., Mugidde, R., Ramlal P.S., Talbot, M.R. and Kling, G.W. 2010. Multiple stressors cause rapid ecosystem change in Lake Victoria. Freshwat. Biol. (suppl. 1) 55: 19-42. doi: 10.1111/j.1365-2427.2009.02374.x

Hickley, P. and Bailey, R.G. 1987. Food and feeding relationships of fish in the Sudd swamps (River Nile, southern Sudan). J. Fish Biol. 30(2): 147-159. doi: 10.1111/j.10958649.1987.tb05741.x 
967

968

969

970

971

972

973

974

975

976

977

978

979

980

981

982

983

984

985

986

987

988

989

Hughes, N.F. 1986. Changes in the feeding biology of the Nile perch Lates niloticus (L.)

(Pisces: Centropomidae), in Lake Victoria, East Africa since its introduction in 1960 and its impact on the native fish community of the Nyanza Gulf. J. Fish Biol. 29(5): 541-548. doi: 10.1111/j.1095-8649.1986.tb04971.x

Hughes, N.F. 1992. Growth and reproduction of the Nile perch, Lates niloticus, an introduced predator, in the Nyanza Gulf, Lake Victoria, East Africa. Environ. Biol. Fish. 33(3): 299305. doi: $10.1007 / \mathrm{BF} 00005874$

Hutchings, J.A. 2014. Renaissance of a caveat: Allee effects in marine fish. ICES J. Mar. Sci. 71(8), 2152-2157. doi:10.1093/icesjms/fst179

Ims, R.A. 1990. On the adaptive value of reproductive synchrony as a predator-swamping strategy. Amer. Nat. 136(4):485-498. doi: org/10.1086/285109

Isumbisho, M., Sarmento, H., Kaningini, B., Micha, J.-.C. and Decsy, J.-P. 2006. Zooplankton of Lake Kivu, East Africa, half a century after the Tanganyika sardine introduction. J. Plankton Res. 28(11): 971-989. doi:10.1093/plankt/fb1032

Ives, A.R. and Carpenter, S.R. 2007. Stability and diversity of ecosystems. Science 317(5834): 58-62. doi: 10.1126/science. 1133258

Jackson, P.B.N. 1961. The impact of predation, especially by the tigerfish (Hydrocyon vittatus Cast.) on African freshwater fishes. Proc. Zool. Soc., Lond. 136(4): 603-622. doi: 10.1111/j.1469-7998.1961.tb05895.x

Jackson, P.B.N. 1971. African great lakes fisheries: past, present and future. Afr. J. Trop. Hydrobiol. Fish. 1: 35-49.

Jackson, P.B.N. 1973. The African Great Lakes: food source and world treasure. Biol. Cons. 5(4): 302-304. doi: http://dx.doi.org/10.1016/0006-3207(73)90164-X 
990

991

992

993

994

995

996

997

998

999

1000

1001

1002

1003

1004

1005

1006

1007

1008

1009

1010

1011

1012

Jackson P.B.N. 2000. Freshwater fishery research organisations in central and eastern Africa: a personal recollection. Trans. Roy. Soc. S. Afr. 55: 1-81. doi: http://dx.doi.org/10.1080/00359190009520421

Jeschke, J.M. and Strayer, D.L. 2005. Invasion success of vertebrates in Europe and North America. Proc. Nat. Acad. Sci. USA 102(20): 7198-7202. doi:10.1073/pnas.0501271102

Katunzi, E.F.B., van Densen, W.L.T., Wanink, J.H. and Witte, F. 2006. Spatial and seasonal patterns in the feeding habits of juvenile Lates niloticus (L.), in the Mwanza Gulf of Lake Victoria. Hydrobiologia 568(1): 121-133. doi:10.1007/s10750-006-0033-3

Katunzi, E. F. B., Zoutendijk, J., Goldschmidt, T., Wanink, J.H. and Witte, F. 2003. Lost zooplanktivorous cichlid from Lake Victoria reappears with a new trade. Ecol. Freshwat. Fish 12(4): 237-240. doi: 10.1046/j.1600-0633.2003.00023.x

Kaufman, L. 1992. Catastrophic change in species-rich freshwater ecosystems: the lessons of Lake Victoria. BioScience 42(11): 846-858. doi:10.2307/1312084

Kaufman, L.S, Chapman, L.J. and Chapman, C.A. 1997. Evolution in fast forward: haplochromine fishes of the Lake Victoria region. Endeavour 21(1):23-30. https://doi.org/10.1016/S0160-9327(96)10034-X

Kaufman, L. and Ochumba P. 1993. Evolutionary and conservation biology of cichlid fishes as revealed by faunal remnants in northern Lake Victoria. Cons. Biol. 7(3): 719-730. doi: 10.1046/j.1523-1739.1993.07030719.x

Kiggundu, V., Mwebaza-Ndawula, L., Makanga, B. and Nachuha, S. 2012. Variations in zooplankton community structure and water quality conditions in three habitat types in northern Lake Victoria. Lakes \& Reservoirs: Res. Manage. 17(2): 83-95. Doi:

10.1111/j.1440-1770.2012.00504.x 
1013 Kishe-Machumu, M., Witte, F. and Wanink, J.H. 2008. Dietary shift in benthivorous cichlids 1014 after the ecological changes in Lake Victoria. Anim. Biol. 58(4): 401-417. doi:

1015 $10.1163 / 157075608 \times 383700$.

1016

1017

1018

1019

1020

1021

1022

1023

1024

1025

1026

1027

1028

1029

1030

1031

1032

1033

1034

1035

1036

Kishe-Machumu, M.A., Voogd, T., Wanink, J.H. and Witte, F. 2015a. Can differential resurgence of haplochromine trophic groups in Lake Victoria be explained by selective Nile perch, Lates niloticus (L.) predation? Environ. Biol. Fish 98:1255-1263. doi: $10.1007 / \mathrm{s} 10641-014-0356-2$

Kishe-Machumu, M.A., van Rijssel, J.C., Wanink, J.A. and Witte, F. 2015b. Differential recovery and spatial distribution pattern of haplochromine cichlids in the Mwanza Gulf of Lake Victoria. J. Great Lakes Res. 41: 454-462. https://doi.org/10.1016/j.jglr.2015.03.005

Kishe-Machumu, M., Witte, F., Wanink, J.H. and Katunzi, E.F.B. 2012. The diet of Nile perch, Lates niloticus (L.) after resurgence of haplochromine cichlids in the Mwanza Gulf of Lake Victoria. Hydrobiologia 682(1): 111-119. doi:10.1007/s10750-011-0822-1

Kitchell, J.F., Schindler, D.E., Ogutu-Ohwayo, R. and Reinthal, P.N. 1997. The Nile perch in Lake Victoria: interactions between predation and fisheries. Ecol. Appl. 7(2): 653-664. doi: 10.1890/1051-0761(1997)007[0653:TNPILV]2.0.CO;2

Kolding, J., van Zwieten, P., Mkumbo, O.C., Silsbe, G. and Hecky R. 2008. Are the Lake Victoria fisheries threatened by exploitation or eutrophication? Towards an ecosystem based approach to management. In The ecosystem approach to fisheries. Edited by G. Bianchi and H.R. Skjoldal. FAO, Rome: pp. 309-354.

Kudhongania, A.W. and Cordone, A.J. 1974. Batho-spatial distribution pattern and biomass estimate of the major demersal fishes in Lake Victoria. Afr. J. Trop. Hydrobiol. Fish. 3: $15-31$. 
1037

1038

1039

1040

1041

1042

1043

1044

1045

1046

1047

1048

1049

1050

1051

1052

1053

1054

1055

1056

1057

1058

1059

1060

1061

Kudhongania, A.W. and Chitamwebwa, D.B.R. 1995. Impact of environmental change, species introductions and ecological interactions on the fish stocks of Lake Victoria. In The impact of species changes in African lakes. Edited by T.J. Pitcher and P.J.B. Hart. Chapman and Hall, London: pp. 19-32.

Lévêque, C. 1997. Biodiversity dynamics and conservation. The freshwater fish of tropical Africa. Cambridge University Press, Cambridge UK.

Liermann, M. and Hilborn, R. (2001) Depensation: evidence, models and implications. Fish Fish. 2: 33-58. doi: 10.1046/j. 1467-2979.2001.00029.x

Ligtvoet, W. and Mkumbo, O.C. 1990. Synopsis of ecological and fishery research on Nile perch (Lates niloticus) in Lake Victoria, conducted by HEST/TAFIRI. In CIFA, Report of the Fifth Session of the Sub-committee for the Development and Management of the Fisheries in Lake Victoria, 12-14 September 1989, Mwanza, Tanzania. FAO Fish. Rep. 430: 35-74. FAO, Rome.

Ligtvoet, W. and Witte F. 1991. Perturbation through predator introduction: effects on the food web and fish yields in Lake Victoria (East Africa). In Terrestrial and aquatic ecosystems: perturbation and recovery. Edited by O. Ravera. Ellis Horwood, New York, pp. 263-268.

Lockwood, J.L., Cassey, P. and Blackburn, T. 2005. The role of propagule pressure in explaining species invasions. Trends Ecol. Evol. 20(5): 223-228.

doi: http://dx.doi.org/10.1016/j.tree.2005.02.004

Lowe-McConnell, R.H. 1987. Ecological studies in tropical fish communities. Cambridge University Press, Cambridge, UK.

McCann, K.S. 2000. The diversity-stability debate. Nature 405(6783): 228-233. doi: $10.1038 / 35012234$

Macdonald, W.W. 1953. Lake-flies. Uganda J. 17:124-134. 
1062

1063

1064

1065

1066

1067

1068

1069

1070

1071

1072

1073

1074

1075

1076

1077

1078

1079

1080

1081

1082

1083

1084

1085

1086

Macdonald, W.W. 1956. Observations on the biology of chaoborids and chironomids in Lake Victoria and on the feeding habits of the "elephant-snout fish" (Mormyrus kannume Forsk.). J. Anim. Ecol. 25(1):36-53. doi: 10.2307/1849

McIntyre, P.B., Jones, L.E., Flecker, A.S. and Vanni, M.J. 2007. Fish extinctions alter nutrient recycling in tropical freshwaters. Proc. Nat. Acad. Sci, USA 104(11): 44614466. doi: 10.1073/pnas.0608148104

MacIntyre, S. 2013. Climate variability, mixing dynamics, and ecological consequences in the African Great lakes. In Climatic change and global warming of inland waters: impacts and mitigations for ecosystems and societies. Edited by C.R. Goldman CR, M. Kamagai and R.D. Robarts. Wiley, New York, pp. 311-336.

MacIntyre, S, Romero, J.R., Silsbe, G.M. and Emery, B.M. 2014. Stratification and horizontal exchange in Lake Victoria, East Africa. Limnol. Oceanogr. 59(6): 1805-1838. doi:10.4319/1o.2014.59.6.1805

McLachlan, A.J. 1970. Some effects of annual fluctuations in water level on the larval chironomid communities of Lake Kariba. J. Anim. Ecol. 39(1):79-90. doi: 10.2307/2890

Marshall, B.E. 1978. Aspects of the ecology of benthic fauna in Lake McIlwaine, Rhodesia. Freshwat. Biol. 8(3): 241-249. doi: 10.1111/j.1365-2427.1978.tb01445.x

Marshall, B.E. (1991). The impact of the introduced sardine Limnothrissa miodon on the ecology of Lake Kariba. Biol. Conserv. 55(2):151-165. https://doi.org/10.1016/00063207(91)90054-D

Marshall, B.E., Ezekiel, C.N., Gichuki, J., Mkumbo, O.C., Sitoki, L. \& Wanda, F. 2013. Has climate change disrupted stratification patterns in Lake Victoria, East Africa? Afr. $J$. Aquat. Sci. 38(3): 249-253. doi: http://dx.doi.org/10.2989/16085914.2013.810140

Marten, G.G. 1979a. Predator removal: effect on fisheries yields in Lake Victoria (East Africa). Science 203(4381): 646-647. doi: 10.1126/science.203.4381.646 
1087

1088

1089

1090

1091

1092

1093

1094

1095

1096

1097

1098

1099

1100

1101

1102

1103

1104

1105

1106

1107

1108

1109

1110

1111

Marten, G.G. 1979b. Impact of fishing on the inshore fishery of Lake Victoria (East Africa). J. Fish. Res. Bd Can. 36(8): 891-900. https://doi.org/10.1139/f79-127

Marx, M. 1978. Structura calitativa si cantitativa a faunei bentonice din Lacul Victoria. (Quantitative and qualitative analysis of the benthic fauna of Lake Victoria). Stud. Cercet. Biol. Ser. Biol. Anim. 30(2):141-147.

Mavuti, K.M. and Litterick, M.R. 1991. Composition, distribution and ecological role of zooplankton community in Lake Victoria, Kenya waters. Verh. Int. Verein. Limnol. 24:1117-1122.

Mbabazi, D., Ogutu-Ohwayo, R., Wandera, S.B., Kizito,Y. 2004. Fish species and trophic diversity of haplochromine cichlids in the Kyoga satellite lakes (Uganda). Afr. J. Ecol. 42(1): 59-68. doi: 10.1111/j.0141-6707.2004.00492.x

Mkumbo, O.C. and Ligtvoet, W. 1992. Changes in the diet of Nile perch, Lates niloticus (L.), in the Mwanza Gulf, Lake Victoria. Hydrobiologia 232(1): 79-83. doi:10.1007/BF00014615

Mkumbo, O.C and Marshall, B.E. 2015. The Nile perch fishery of Lake Victoria: current status and management challenges. Fish. Manage. Ecol. 22(1): 56-63.

DOI: $10.1111 / \mathrm{fme} .12084$

Mkumbo, O.C, Tumwebaze, R. and Getabu, A. 2005. Trends in the composition, abundance and distribution of the fishes. In The state of the fisheries resources of Lake Victoria and their management. Proceedings of the Regional Stakeholders' Conference, 24-25 May 2005, Entebbe, Uganda. Lake Victoria Fisheries Organisation, Jinja, Uganda: pp. 73-84.

Mnyanga, V.P., Osio, J.O., Mwebembezi, L., Myanza, O.I., Opango, P.O., Majaliwa, J.G.M., Oleko, C.O., Okwerede, L., Gor, S.A., Byamukama, D., Mathayo, A.A., Masongo, F.O., Kanyesigye, C., Kitamirike, J.M., Semalulu, and Hecky, R.E. 2005. Chapter 7: nutrient loading. In Lake Victoria Water Quality Synthesis Report. Edited by F.L. Mwanuzi, 
1112

1113

1114

1115

1116

1117

1118

1119

1120

1121

1122

1123

1124

1125

1126

1127

1128

1129

J.O.Z. Abuodha, F.J. Muyodi and R.E. Hecky. Lake Victoria Environmental Management Project, Kisumu, Kenya: pp. 103-140.

Moreau, J. 1982. Exposé synoptique des donnês biologiques sur la perche du Nil Lates niloticus (Linnaeus, 1762). FAO Synopsis sur la pêches (132): 44 pp.

Moriarty, C.M. and Moriarty, D.J.W. 1973. Quantitative estimation of the daily ingestion of phytoplankton by Tilapia nilotica and Haplochromis nigripinnis in Lake George, Uganda. J. Zool. 171: 15-24. doi: 10.1111/j.1469-7998.1973.tb07513.x

Mugidde, R. 1993. The increase in phytoplankton primary productivity and biomass in Lake Victoria (Uganda). Verh. Internat. Verein. Limnol. 25: 846-849.

Muli, J.R. 2005. Spatial variation of benthic macroinvertebrates and the environmental factors influencing their distribution in Lake Victoria, Kenya. Aquat. Ecosyst. Health Manage. 8: 147-157. doi: 10.1080/14634980590953680

Mwebaza-Ndawula, L., Kiggundu, V. and Gandhi, W.P. 2004. The ststus and significance of invertebrate communities. In Challenges for management of the fisheries resources, biodiversity and environment of Lake Victoris. Edited by J.S. Balirwa, R. Mugidde and R. Ogutu-Ohwayo. Fisheries Resources Research Institute, Jinja, Uganda: pp. 153-171.

Ngupula, G.W., Waya, R.K. and Ezekiel, C.N. 2010. Spatial and temporal patterns in abundance and distribution of zooplankton in the Tanzanian waters of Lake Victoria. Aquat. Ecosyst. Health Manage. 13(4): 451-457. doi: 10.1080/14634988.2010.525077

Njiru, M., Okeyo-Owuor, J.B., Muchiri, M. and Cowx I.G. 2004. Shifts in the food of Nile tilapia, Oreochromis niloticus (L.) in Lake Victoria, Kenya. Afr. J. Ecol. 42: 163-170. doi: 10.1111/j.1365-2028.2004.00503.x

Nkalubo, W., Chapman, L. and Muyodi, F. 2014. Feeding ecology of the intensively fished Nile Perch, Lates niloticus, in Lake Victoria, Uganda. Aquat. Ecosyst. Health Manage 17: 62-69. doi: 10.1080/14634988.2014.880639 
1137

1138

1139

1140

1141

1142

Nyboer, E.A., Gray, S.M. and Chapman, L.J. 2014. A colourful youth: ontogenetic colour change is habitat specific in the invasive Nile perch. Hydrobiologia 738:221-234. doi: 10.1007/s10750-014-1961-y

Ochumba, P.B.O. 1988. Periodic massive fish kills in the Kenyan portion of Lake Victoria. In: Report of the Fourth Session of the Sub-Committee for the Development and Management of the Fisheries of Lake Victoria. FAO Fish. Rep. (388): 47-60.

Ochumba, P.B.O. 1990. Massive fish kills within the Nyanza Gulf of Lake Victoria, Kenya. Hydrobiologia 208(1): 93-99. doi:10.1007/BF00008448

Ochumba, P.B.O. 1995. Limnological changes in Lake Victoria since the Nile perch introduction. In The Impact of species changes in African lakes. Edited by T.J. Pitcher and P.J.B. Hart. Chapman and Hall, London, pp. 33-43.

Ochumba, P.B.O. and Kibaara, D.I. 1989. Observations on blue-green algal blooms in the open waters of Lake Victoria, Kenya. Afr. J. Ecol. 27(1): 23-34. doi: 10.1111/j.13652028.1989.tb00925.x

Ogari, J. and Dadzie, S. 1988. The food of the Nile perch, Lates niloticus (L.), after the disappearance of the haplochromine cichlids in the Nyanza Gulf of Lake Victoria (Kenya). J. Fish Biol. 32(4): 571-577. doi: 10.1111/j.1095-8649.1988.tb05396.x

Ogutu-Ohwayo, R. 1988. Reproductive potential of the Nile perch Lates niloticus L. and the establishment of the species in Lake Kyoga and Victoria, East Africa. Hydrobiologia 162(3): 193-200. doi: 10.1007/BF00016667

Ogutu-Ohwayo, R. 1990a. The decline of the native fishes of Lakes Victoria and Kyoga (East Africa) and the impact of introduced species, especially the Nile perch, Lates niloticus and the Nile tilapia, Oreochromis niloticus. Environ. Biol. Fish. 27(2): 81-96. doi: 10.1007/BF00001938 
1161

1162

1163

1164

1165

1166

1167

1168

1169

1170

1171

1172

1173

1174

1175

1176

1177

1178

1179

1180

1181

1182

1183

1184

1185

Ogutu-Ohwayo, R. 1990b. Changes in the prey ingested and the variations in the Nile perch and other fish stocks of Lake Kyoga and the northern waters of Lake Victoria (Uganda). J. Fish Biol. 37(1): 55-63. doi: 10.1111/j.1095-8649.1990.tb05926.x

Ogutu-Ohwayo, R. 1995. Diversity and stability of fish stocks in lakes Victoria, Kyoga and Nabugabo after establishment of introduced species. In The impact of species changes in African lakes. Edited by T.J. Pitcher and P.J.B. Hart. Chapman and Hall, London, pp. 5981.

Ogutu-Ohwayo, R. 1999. Deterioration in length-weight relationships of Nile perch, Lates niloticus L. in lakes Victoria, Kyoga and Nabugabo. Hydrobiologia 403: 81-86. doi: 10.1023/A:1003720022870

Ogutu-Ohwayo, R., Odongkara, K, Okello, W., Mbabazi, D., Wandera, S.B., Ndawula, L.M. and Natugonza, V. 2013. Variations and changes in habitat, productivity, composition of aquatic biota and fisheries of the Kyoga lake system: lessons for management. Afr. J. Aquat. Sci. 38 (suppl. 1): 1-14. doi: 10.2989/16085914.2013.795886.

Okaronon, J.O., Muhoozi, L.I and Bassa, S. 1999. Current status of the fish stocks of Lake Victoria (Uganda). In Report on fourth FIDA WOG workshop, Kisumu, Kenya, 16-20 August 1999. Edited by I.G. Cowx and D. Tweddle. Lake Victoria Research Project, Phase II: pp. 10-25.

Okaronon, J.O. and Ntiba, M.J. 2000. Current state of the fish stocks in the Ugandan waters of Lake Victoria. In Proceedings of the Lake Victoria 2000 conference: a new beginning, 15-19 May 2000, Jinja, Uganda. Lake Victoria Fisheries Organisation, Jinja, Uganda: pp. 142-153.

Okedi, J. 1970. Further observations on the ecology of the Nile perch (Lates niloticus Linné) in Lake Victoria and Lake Kioga. In EAFFRO Ann. Rep., 1969:42-55. East African Freshwater Fisheries Research Organisation, Jinja, Uganda. 
1186

1187

1188

1189

1190

Paterson, J.A. and Chapman, L.J. 2009. Fishing down and fishing hard: ecological change in the Nile perch of Lake Nabugabo, Uganda Ecol. Freshwat. Fish 18(3): 380-394. doi: 10.1111/j.1600-0633.2009.00355.x

Payne I. 1987. A lake perched on piscine peril. New Scientist, 27 August 1987: 50-54.

Pelicice, F.M. and Agostinho, A.A. 2009. Fish fauna destruction after the introduction of a non-native predator (Cichla kelberi) in a Neotropical reservoir. Biol. Invas. 11(8):1789_ 1801. doi:10.1007/s10530-008-9358-3

Pitt, W.C. and Wilmer, G.W. 2007. Invasive predators: a synthesis of the past, present and future. In Predation in organisms. Edited by A.T. Elewa. Springer, Berlin: pp. 265-293.

Pringle, R.M. 2005. The origins of the Nile perch in Lake Victoria. BioScience 55 (9): 780 787. doi:10.1641/0006-3568(2005)055[0780:TOOTNP]2.0.CO;2

Reynolds, J.E. and Greboval, D.F. 1988. Socio-economic effects of the evolution of Nile perch fisheries in Lake Victoria: a review. CIFA Tech..Pap. (17):148 p. FAO, Rome.

Ruttner, F. 1953. Fundamentals of limnology, $2^{\text {nd }}$ edition (translated by D.G. Frey and F.E.J. Frey). University of Toronto Press, Toronto.

Scheffer, M., Carpenter, S., Foley, J.A., Folke, C. and Walke, B. 2001. Catastrophic shifts in ecosystems. Nature 413: 591-596. doi:10.1038/35098000

Sekiranda, S.B.K., Okut-Okumu, J., Bugenyi, F.W.B., Ndawula, L.M. and Gandhi, P. 2004. Variation of composition of macro-invertebrates as an indication of water quality status in three bays in Lake Victoria. Uganda J. Agric. Sci. 9: 396-411.

Seehausen, O., van Alphen J.J.M. and Witte, F. 1997. Cichlid fish diversity threatened by eutrophication that curbs sexual selection. Science 277(5333): 1808-1811. doi: 10.1126/science.277.5333.1808.

Seehausen, O., van Alphen, J. J. M., Witte, F., 2003. Implications of eutrophication for fish vision, behavioral ecology and species coexistence. In Conservation, Ecology, and 
1211

1212

1213

1214

1215

1216

1217

1218

1219

1220

1221

1222

1223

1224

1225

1226

1227

1228

1229

1230

1231

1232

1233

1234

Management of African Freshwaters. Edited by T. L. Crisman, L. J. Chapman, C. A. Chapman, and L. S. Kaufman. University Press of Florida, Gainesville, Florida. pp. 268287.

Seehausen, O., Witte, F., Katunzi, E.F., Smits, J. and Bouton, N. 1997b. Patterns of the remnant cichlid fauna in southern Lake Victoria. Cons. Biol. 11(4): 890-904. doi: 10.1046/j.1523-1739.1997.95346.x

Shigesada, N., Kawasaki, K. and Takeda, Y. 1995. Modeling stratified diffusion biological invasions. Am. Nat. 146(2): 229-251. doi: 10.1086/285796

Simberloff, D. 2009. The role of propagule pressure in biological invasions. Ann. Rev. Ecol. Evol. Syst. 40: 81-102.

Sitoki, L., Gichuki, J., Ezekiel, C., Wanda, F., Mkumbo, O.C. and Marshall, B.E. (2010) The environment of Lake Victoria (East Africa): current status and historical changes. Internat. Rev. Hydrobiol. 95(3): 209-223. doi: 10.1002/iroh.201011226

Song, Y., Semazzi, F.H.M., Xie, L. and Ogallo, L.J. 2004. A coupled regional climate model for the Lake Victoria basin of East Africa. Int. J. Climatol. 24: 57-75. doi: $10.1002 /$ joc. 983

Stager, J.C., Hecky, R.E., Grzesik, D., Cumming, B.F. and Kling, H. 2009. Diatom evidence for the timing and causes of eutrophication in Lake Victoria, East Africa. Hydrobiologia 636(1): 463-478. doi:10.1007/s10750-009-9974-7

Stoneman, J., Meecham, K.B. and Mathotho. A.J. 1973. Africa's Great Lakes and their fisheries potential. Biol. Cons. 5:(4): 299-302. doi: https://doi.org/10.1016/00063207(73)90163-8

Taabu-Munyaho A, Kayanda, R.J, Everson I, Grabowski TB, Marteinsdóttir, G. (2013). Distribution and exploitation of Nile perch Lates niloticus in relation to stratification in 
1235

1236

1237

1238

1239

1240

1241

1242

1243

1244

1245

1246

1247

1248

1249

1250

1251

1252

1253

1254

1255

1256

1257

1258

1259

Lake Victoria, East Africa. J. Great Lakes Res. 39(3): 466-475.

https://doi.org/10.1016/j.jglr.2013.06.009

Taabu-Munyaho, A, Nyamweya, C.S., Sitoki, L., Kayanda, R., Everson, I. and

Marteinsdóttir, G. 2014. Spatial and temporal variation in the distribution and density of pelagic fish species in Lake Victoria, East Africa. Aquat. Ecosyst. Health Manage. 17(1): 52-61. http://dx.doi.org/10.1080/14634988.2014.876886

Taabu-Munyaho, A, Marshall, B.E., Tomasson, T. and Marteinsdottir, G. 2016. Nile perch and the transformation of Lake Victoria. Afr. J. Aquat. Sci. 41(2): 127-142. doi: $10.2989 / 16085914.2016 .1157058$

Talling, J.F. 1966. The annual cycle of stratification and phytoplankton growth in Lake Victoria (East Africa). Int. Rev. ges. Hydrobiol. 51(4): 545-621. doi: 10.1002/iroh.19660510402

Talling, J.F. 1987. The phytoplankton of Lake Victoria (East Africa). Archiv Hydrobiol. Beiheft Ergebn. Limnol. 25: 229-256.

Talling, J.F. and Lemoalle, J. 1998. Ecological dynamics of tropical inland waters. Cambridge University Press, Cambridge, UK.

van de Wolfshaar, K.E., HilleRisLambers, R., Goudswaard, K.P.C., Rijnsdorp, A.D. and Scheffer, M. (2014) Nile perch (Lates niloticus, L.) and cichlids (Haplochromis spp.) in Lake Victoria: could prey mortality promote invasion of its predator? Theor. Ecol. 7(3): 253-261. doi:10.1007/s12080-014-0215-y

van Rijssel, J.C., Hecky, R.E., Kishe-Machumu, M.A. and Witte, F. (2017) Changing ecology of Lake Victoria cichlids and their environment: evidence from $\mathrm{C}^{13}$ and $\mathrm{N}^{15}$ analyses. Hydrobiologia 791(1): 175-191. doi:10.1007/s10750-016-2790-y. van Zwieten, P.A.M., Kolding, J., Plank, M.J., Hecky, R.E., Bridgeman, T.B., MacIntyre, S., Seehausen, O. and Silsbe, G.M. 2016. The Nile perch invasion in Lake Victoria: cause or 
1260

1261

1262

1263

1264

1265

1266

1267

1268

1269

1270

1271

1272

1273

1274

1275

1276

1277

1278

1279

1280

1281

1282

1283

consequence of the haplochromine decline? Can. J. Fish. Aquat. Sci. 73(4): 622-643. doi: dx.doi.org/10.1139/cjfas-2015-0130

Verschuren, D., Johnson, T.C., Kling H.J., Edgington, D.N., Leavitt, P.R., Brown, E.T., Talbot, M.R. and Hecky, R.E. 2002. History and timing of human impact on Lake Victoria, East Africa. Proc. Roy. Soc., Lond. B 269(1488): 289-294. doi: $10.1098 / \mathrm{rspb} .2001 .1850$

Wanink, J.H., Kashindye, J.J., Goudswaard, P.C. and Witte, F. 2001. Dwelling at the oxycline: does increased stratification provide a predation refugium for the Lake Victoria sardine Rastrineobola argentea. Freshwat. Biol. 46(1): 75-85. doi: 10.1111/j.13652427.2001.00644.x

Waya RK \& Mwambungu JA (2004). Zooplankton communities of selected stations of Lake Victoria. Tanzanian J. Sci. 30(1): 11-20.

Welcomme, R.L. 1964. Notes on the present distribution and habits of the non-endemic species of Tilapia which have been introduced into Lake Victoria. In EAFFRO Ann. Rep., 1962-63:36-39. East African Freshwater Fisheries Research Organisation, Jinja, Uganda.

Welcomme, R.L. (1965) Notes on the Haplochromis of the Bugungu Lagoon, Lake Victoria. In EAFFRO Ann. Rep., 1964: 32-42. East African Freshwater Fisheries Research Organisation, Jinja, Uganda.

Welcomme, R.L. 1985. River fisheries. FAO Fish. Tech. Pap. (262): 330 pp.

Witte, F., Goldschmidt T., Wanink J., van Oijen, M., Goudswaard, K., Witte-Maas E. and Bouton N. 1992. The destruction of an endemic species flock: quantitative data on the decline of the haplochromine cichlids of Lake Victoria. Environ. Biol. Fish. 34(1): 1-28. doi: $10.1007 / \mathrm{BF} 00004782$ 
1284

1285

1286

1287

1288

1289

1290

1291

1292

1293

1294

1295

1296

1297

1298

1299

1300

1301

1302

1303

1304

1305

1306

1307

1308

Witte, F., Goldschmidt, T. and Wanink, J.H. 1995a. Dynamics of the haplochromine cichlid fauna and other ecological changes in the Mwanza Gulf of Lake Victoria. In The impact of species changes in African lakes. Edited by T.J. Pitcher and P.J.B. Hart. Chapman and Hall, London, pp. 83-110.

Witte, F. and Goudswaard, P.C. 1984. Aspects of the haplochromine fishery in southern Lake Victoria. In Report of the Third Session of the Sub-Committee for the Development and Management of the Fisheries of Lake Victoria, 4-5 October 1984, Jinja, Uganda. FAO Fish. Rep. (335): 81-88.

Witte, F., Msuku, B. S., Wanink, J. H., Seehausen, O., Katunzi, E. F. B., Goudswaard, P. C., Goldschmidt, T., 2000. Recovery of cichlid species in Lake Victoria: an examination of factors leading to differential extinction. Rev. Fish Biol. Fish. 10(2):233-241. doi:10.1023/A:1016677515930

Witte, F., Seehausen, O., Wanink, J.H., Kishe-Machumu, M.A., Rensing, M., Goldschmidt, T. 2013. Cichlid species diversity in naturally and anthropogenically turbid habitats of Lake Victoria, East Africa. Aquat. Sci. 75(2):169-183. doi: 10.1007/s00027-012-0265-4

Witte, F. and van Oijen, M.J.P. (1995) Biology of haplochromine trophic groups. In Fish stocks and fisheries of Lake Victoria. Edited by F. Witte and W.L.T. van Densen. Samara Publishing, Cardigan, UK, pp. 321-335.

Witte, F., Wanink, J.H., Kishe-Machumu, M., Mkumbo, O.C., Goudswaard, P.C. and Seehausen, O. 2007a. Differential decline and recovery of haplochromine trophic groups in the Mwanza Gulf of Lake Victoria. Aquat. Ecosyst. Health Manage. 10(4): 416-433. doi: http://dx.doi.org/10.1080/14634980701709410

Witte, F., Wanink, J.H. and Kishe-Machimu, M. 2007b. Species distinction and the biodiversity crisis in Lake Victoria. Trans. Amer. Fish. Soc. 136(4): 1146-1159. doi: http://dx.doi.org/10.1577/T05-179.1 
1309 Witte, F., Wanink, J.H., Rutjes, H.A., van der Meer, H.J and van den Thillart, G.E.E.J.M.

1310 2005. Eutrophication and its influences on the fish fauna of Lake Victoria. In Restoration 1311 and management of tropical eutrophic lakes. Edited by M.V. Reddy. Science Publishers, 1312 Enfield, New Hampshire, USA: pp. 301-338.

1313 Witte, F., Welten, M., Heemskerk, M., van der Stap, I., Ham, L., Rutjes, H. and Wanink, J. 1314 2008. Major morphological changes in a Lake Victoria cichlid fish within two decades.

1315 Biol. J. Linn. Soc. 94(1): 41-52. doi: 10.1111/j.1095-8312.2008.00971.x

1316 Worthington, E.B. 1972. The ecology of introductions - a case study from the African lakes.

1317 Biol. Cons. 5(3):221-222. doi: https://doi.org/10.1016/0006-3207(73)90019-0

1318 Zaret, T.M. and Paine, R.T. 1973. Species introduction in a tropical lake. Science 182(4111):

1319 449-455. doi: 10.1126/science.182.4111.449

1320 
1321 Table 1. Age structure (\%) of Nile perch at the Massesse Fish Market, Jinja, Uganda, 1964-

1322 1977. Values $>20 \%$ are highlighted for clarity. Data from Acere (1984).

1323

\begin{tabular}{lccccc}
\hline Age (years) & 1 & $2-3$ & $4-5$ & $6-10$ & $>10$ \\
\hline $1964 / 65$ & $\mathbf{9 9 . 6}$ & 0.4 & & & \\
$1965 / 66$ & $\mathbf{9 9 . 6}$ & 0.3 & 0.1 & & \\
$1966 / 67$ & $\mathbf{9 7 . 2}$ & 2.2 & 0.3 & 0.3 & \\
$1967 / 68$ & $\mathbf{7 3 . 1}$ & $\mathbf{2 5 . 7}$ & 0.6 & 0.6 & \\
$1968 / 69$ & $\mathbf{7 7 . 3}$ & $\mathbf{2 0 . 8}$ & 1.1 & 0.8 & \\
$1969 / 70$ & 3.6 & $\mathbf{5 7 . 2}$ & 7.1 & $\mathbf{3 2 . 1}$ & \\
$1970 / 71$ & 0 & 7.9 & $\mathbf{2 5 . 4}$ & $\mathbf{6 3 . 5}$ & 3.2 \\
$1974 / 75$ & 0 & 1.0 & 9.4 & $\mathbf{8 2 . 3}$ & 7.3 \\
$1975 / 76$ & 0.7 & 2.8 & 17.6 & $\mathbf{7 0 . 4}$ & 8.5 \\
$1976 / 77$ & $\mathbf{2 8 . 7}$ & 2.3 & 5.8 & $\mathbf{5 4 . 0}$ & 9.2 \\
\hline
\end{tabular}

1324 
1325 Table 2. The relative abundance $\left(\mathrm{kg} \mathrm{hour}^{-1}\right)$ of demersal fish species caught in bottom trawls 1326 in the Ugandan waters of Lake Victoria. From Kudhongania and Cordone (1974) and Acere 1327 (1988). The symbol * indicates an introduced species, dashes indicate zero values; the 1328 original data do not include confidence limits.

1329

\begin{tabular}{lrrrrrrrr}
\hline & $1969-71$ & 1981 & 1982 & 1983 & 1984 & 1985 & 1986 \\
\hline Haplochromis spp. & 327.4 & 391.7 & 295.7 & 264.6 & 113.9 & 17.8 & - \\
Lates niloticus $*$ & 0.5 & 3.5 & 45.3 & 54.3 & 140.2 & 234.7 & 80.1 \\
Oreochromis niloticus $*$ & 0.9 & 12.2 & 7.3 & 5.2 & 1.8 & 5.0 & 7.1 \\
O. esculentus & 2.6 & 0.5 & 0.1 & - & - & - & - \\
O. variabilis & 0.6 & 5.6 & 2.5 & 0.9 & - & - & - \\
Bagrus docmak & 23.5 & 9.0 & 9.3 & 11.3 & 4.3 & 1.5 & 0.3 \\
Clarias gariepinus & 17.3 & 14.4 & 8.0 & 4.4 & 1.8 & 0.1 & - \\
Protopterus aethiopicus & 5.8 & 4.9 & 0.1 & 0.8 & 0.6 & 0.1 & - \\
Synodontis spp. & 15.4 & 2.9 & 0.5 & 0.4 & 0.2 & 0.1 & - \\
Other species & 0.9 & 0.2 & 1.6 & 4.7 & 0.3 & 0.3 & - \\
\hline Total & 394.9 & 444.9 & 370.4 & 346.6 & 264.3 & 259.6 & 87.5 \\
\hline
\end{tabular}


1331 Table 3. The biomass $\left(\mathrm{kg} \mathrm{ha}^{-1}\right)$ of dominant fish species in bottom trawls in the Kenyan

1332 waters of Lake Victoria (from Ochumba 1995). Dashes indicate zero values; the original data 1333 do not include confidence limits.

1334

\begin{tabular}{lrrcrr}
\hline & $1969-71$ & 1975 & 1977 & $1982-83$ & $1989-90$ \\
\hline Haplochromines & 35.8 & 32.7 & 28.7 & - & 0.5 \\
Nile perch & - & 0.8 & 2.8 & 29.0 & 32.7 \\
Other species & 17.2 & 26.6 & 4.4 & 3.3 & 1.3 \\
\hline Total & 53.0 & 60.1 & 35.9 & 32.3 & 34.5 \\
\hline
\end{tabular}


1336 Table 4. The diet of Nile perch $<20 \mathrm{~cm}$ TL in Lake Victoria. Values from 1982 and 1983

1337 were collected shortly after the haplochromine collapse, while those from 2006-08 are after

1338 the haplochromines had begun to recover. Data are expressed as percentages, by numbers

1339 from Kenya, by frequency of occurrence from Tanzania and by Index of Relative Importance

1340 from Uganda (from Ogari and Dadzie 1988; Hughes 1986; Kishe-Machumu et al. 2012;

$1341 \quad$ Nkalubo et al. 2014).

1342

\begin{tabular}{lrrrr}
\hline & Kenya & Kenya & Tanzania & Uganda \\
& 1982 & 1983 & $2006-08$ & $2006-08$ \\
& $(\% \mathrm{~N})$ & $(\% \mathrm{~N})$ & $(\% \mathrm{~F})$ & $(\% \mathrm{IRI})$ \\
& 1.0 & & 0.5 & \\
& 6.0 & 1.0 & 1.5 & 9.0 \\
Nile perch & 2.0 & & 18.7 & 3.8 \\
Dagaa & 79.0 & 88.0 & 77.8 & 33.5 \\
Haplochromines & 12.0 & 3.7 & 5 & 30.2 \\
Caridina (shrimps) & & 7.3 & 9.1 & 22.0 \\
Other invertebrates & & & & 1.5 \\
Unidentified fish remains & & & & \\
Other items & & & & \\
\end{tabular}


1344 Table 5. Mean and relative fecundity in some Lake Victoria fishes. Haplochromine and 1345 dagaa data from Duponchelle et al. (2008), Nile perch data from Ogutu-Ohwayo (1988). 1346

\begin{tabular}{lrrrr} 
& & Weight & Fecundity & \multicolumn{2}{c}{ Relative fecundity } \\
& Habitat & $(\mathrm{g})$ & $(\mathrm{no})$ & $\left(\mathrm{no} \mathrm{kg}^{-1}\right)$ \\
\hline Haplochromines & Pelagic (6 spp.) & 6.3 & 25.2 & 4,408 \\
& Benthic (10 spp.) & 12.6 & 60.3 & 6,526 \\
& Rocks (3 spp.) & 14.3 & 28.3 & 2,862 \\
& & & & 583,000 \\
Dagaa & & 2,000 & 805,000 & 402,500 \\
Nile perch & & 5,000 & $1,195,000$ & 239,000 \\
& & 10,000 & $1,845,000$ & 184,500
\end{tabular}


1349 Table 6. The estimated biomass ( $\mathrm{t}$ x 1000) of Nile perch, dagaa, haplochromines and shrimps 1350 in Lake Victoria (mean values). Data from Everson et al. (2013), Taabu-Munyaho et al. 1351 (2016), and reports of the Acoustic Working Group, Lake Victoria Fisheries Organisation. 1352

\begin{tabular}{lrrcr}
\cline { 2 - 5 } & Nile perch & Dagaa & Haplochromines & Shrimps \\
\hline $1999-2001$ & 932.2 & 518.1 & 277.5 & \\
$2005-2010$ & 455.7 & 980.7 & 524.3 & \\
$2014-2016$ & $1,142.6$ & $1,135.2$ & 426.6 & 251.9 \\
\hline
\end{tabular}

1353 
1354 Table 7. The mean number of haplochromines in the major trophic groups caught in the

1355 Nyanza Gulf, 1979-1992. Data are from station G and are expressed as the mean number in a 1356 10-minute bottom trawl. From Witte et al. (1995).

1357

\begin{tabular}{lrrrrrr}
\hline \multicolumn{1}{c}{ Main trophic group } & $1979-80$ & $1981-82$ & $1983-84$ & $1985-86$ & $1987-88$ & $1990-92$ \\
\hline Detritus/phytoplankton & 1101.2 & 791.2 & 216.3 & 18.8 & 0 & 1.0 \\
Zooplankton & 153.1 & 187.9 & 45.7 & 62.8 & 0.3 & 18.3 \\
Insects & 25.6 & 15.5 & 1.1 & 0 & 0 & 0 \\
Molluscs & 5.4 & 0.5 & 0.1 & 0 & 0 & 0 \\
Fish & 3.5 & 2.0 & 0.1 & 0 & 0 & 0 \\
Other items & 32.8 & 7.3 & 0.1 & 0 & 0 & 0 \\
\hline Total & 1321.5 & 1004.4 & 263.5 & 81.5 & 0.3 & 19.3 \\
& & & & & & \\
\end{tabular}


1359 Table 8. The biomass $\left(\mathrm{kg} \mathrm{ha}^{-1}\right)$ of haplochromines and Nile perch in the Nyanza Gulf, Kenya, 1360 1969-77. The values in brackets represent the annual rate of change (\%) between 1975 and 1361 1977. From Muller and Benda (1981).

1362

\begin{tabular}{lrrr} 
& $1969-70$ & 1975 & 1977 \\
\hline Haplochromines & 35.8 & 32.7 & $28.6 \quad(-6.5)$ \\
Nile perch & 0 & 0.8 & $2.8(169.0)$
\end{tabular}

1363

1364 
1365 Table 9. Changes in the mean ( \pm standard deviation) Secchi disc visibility (m) measured in 1366 inshore $(<20 \mathrm{~m})$ and offshore $(>20 \mathrm{~m})$ waters of Lake Victoria during lake wide surveys.

1367 Data from Graham (1929) and Sitoki et al. (2010).

1368

\begin{tabular}{lcc}
\hline \multicolumn{1}{c}{ Date } & Inshore & Offshore \\
\hline 1927 & $2.2 \pm 0.84$ & $7.5 \pm 1.9$ \\
$2000-01$ & $2.0 \pm 0.62$ & $3.2 \pm 1.1$ \\
$2006-09$ & $1.4 \pm 0.62$ & $3.3 \pm 1.2$ \\
\hline
\end{tabular}

1369 
1370 Table 10. Estimates of the density of dipteran larvae in the sediments of Lake Victoria, 1951137152 to 2001-02. The symbol '+' indicates that Chaoborus were present but in insignificant 1372 numbers. The estimate from Marx (1978) is an approximation; she presented the data in an 1373 unusual form and this value is based on her station V9, which recorded the highest density of 1374 invertebrates. She did not report any Chaoborus.

1375

\begin{tabular}{lccl}
\hline \multicolumn{1}{c}{ Locality } & $\begin{array}{c}\text { Density } \\
\left.\text { (no. } \mathrm{m}^{-2}\right)\end{array}$ & Chaoborus & \\
& & & \multicolumn{1}{c}{ Source } \\
\hline Ekunu Bay, Uganda, 1951-52 & 3000 & 75 & MacDonald (1953) \\
"Lake Victoria", 1970-72 & 1700 & & Marx (1978) \\
Northern waters, 1995-97 & 1266 & 66 & Mwebaza-Ndawula et al. (2004) \\
Kenyan waters, 1996-97 & 330 & & Muli (2005) \\
Fielding Bay, Uganda, 2001-02 & 1104 & + & Sekiranda et al. (2004) \\
Hannington Bay, 2001-02 & 276 & 22 & Sekiranda et al. (2004) \\
Murchison Bay, 2001-02 & 459 & + & Sekiranda et al. (2004) \\
\hline
\end{tabular}


1378 Table 11. Catch rates $\left(\mathrm{kg}\right.$ hour $\left.{ }^{-1}\right)$ of haplochromines ("Haplos") and Nile perch in relation to 1379 depth in Lake Victoria, 1969-71 and 1997-99. Data for 1969-71 are for the lake as a whole 1380 since Kudhongania and Cordone (1974) did not give catch rates by species for each country; 1381 1997-99 values are from Uganda (Okaronon et al. 1999) since there were no comparable data 1382 from the other countries.

1383

\begin{tabular}{ccccc}
\hline & \multicolumn{2}{c}{$1969-71$} & \multicolumn{2}{c}{$1997-99$} \\
\cline { 2 - 5 } Depth (m) & Haplos & Nile perch & Haplos & Nile perch \\
\hline $0-9$ & 493.8 & 2.0 & 3.7 & 173.5 \\
$10-19$ & 800.2 & 0.6 & 2.9 & 136.3 \\
$20-29$ & 639.5 & 0.4 & 1.5 & 168.3 \\
$30-39$ & 507.5 & & 1.5 & 137.9 \\
$40-49$ & 448.0 & & 1.1 & 30.9 \\
$50-59$ & 486.3 & & 0.2 & 9.9 \\
$60-69$ & 196.3 & & & \\
$70-79$ & 29.6 & & & \\
\hline
\end{tabular}




\section{FIGURE CAPTIONS}

Figure 1. Lake Victoria, showing places mentioned in the text, including the location of the deep-water sediment core V96-5MC.

Figure 2. The catch of haplochromines and Nile perch in the Kenyan sector of Lake Victoria, 1968-1988, plotted as natural logarithms to indicate the exponential growth of Nile perch between 1969 and 1983. The catch per unit effort (CPUE) is indicated by the shaded columns, the broken vertical lines denote the 1976-83 climatic event; the symbol $\boldsymbol{\Delta}$ denotes haplochromine values of zero, which cannot be shown on a logarithmic plot. Data from Achieng (1990) and Asila (1997).

Figure 3. Changes in the catch of haplochromines and Nile perch catch in (a) Tanzania, all areas, 1969-1987 (from Reynolds and Greboval (1988); Bwathondi (1990); Mkumbo and Cowx (1999); (b) Mwanza Gulf, 1973-1990 (from Goudswaard et al. 2008). The vertical broken lines indicate the 1976-83 climatic event, symbols are the same in both panels.

Figure 4. Changes in the diet of Nile perch, 1964-2008. The bars show the proportion of five major food sources in the diet; items such as insects or molluscs are omitted because their numbers were too low to be shown in the figure. Uganda data from Gee (1964) and OgutuOhwayo (1990b), Kenya data from Hughes (1986) and Ogari and Dadzie (1988), Tanzania 1407 data from Mkumbo and Ligtvoet (1992) and Kishe-Machumu et al. (2012).

1408

Figure 5. The relative abundance of haplochromines (same symbols in all panels) in the northern waters of Lake Victoria in relation to some variables in sediment cores. Ugandan 
1411

1412

1413

1414

1415

1416

1417

1418

1419

1420

1421

1422

1423

1424

1425

1426

1427

1428

1429

1430

1431

1432

1433

1434

1435

3

catch rates have been divided by 10 to align them with those from Kenya. The broken vertical lines indicate the 1976-83 climatic event. (a) Phosphorus concentrations in sediments at site V96-5MC (solid line), from Hecky et al. 2010); (b) The number of Aulacoseira valves, from van Zwieten et al. (2016); (anomalies in the number of cladoceran fossils, from van Zwieten et al. (2016). Haplochromine data from Kudhongania and Cordone (1974), Acere (1988) and Ochumba (1995).

Figure 6. The relationship between cladoceran abundance in Grant Bay, Uganda, and Nile perch densities in trawl samples from Uganda. Data from van Zieten et al. (2016), Kudhongania and Cordone (1974) and Acere (1988).

Figure 7. (a) The catch rates $\left(\mathrm{kg}_{\mathrm{g}}\right.$ hour $\left.{ }^{-1}\right)$ of Nile perch caught by commercial trawlers in the Speke Gulf, Tanzania, 1986-1990. $\bigcirc=$ fish $>35 \mathrm{~cm} \mathrm{TL,} \bigcirc=$ fish $>35 \mathrm{~cm}$ TL. The horizontal lines indicate the average catch for fish $>35 \mathrm{~cm}$ in each year. Data from Goudswaard et al. (2008). (b) The length frequency distribution of Nile perch caught in bottom trawls, 2006 (N $=3843$ ) and the proportion of haplochromines (points) in their diet in relation to length. The triangles indicate the length at 50\% maturity of male (M) and female (F) Nile perch. Lengthfrequency and maturity data from LVFO (unpublished), haplochromine data from KisheMachumu (2012).

Figure 8. Catch rates of haplochromines and Nile perch in bottom trawls, in relation to depth, Emin Pasha Gulf, Tanzania, June 1985. Data from Goudswaard and Ligtvoet (1987). 


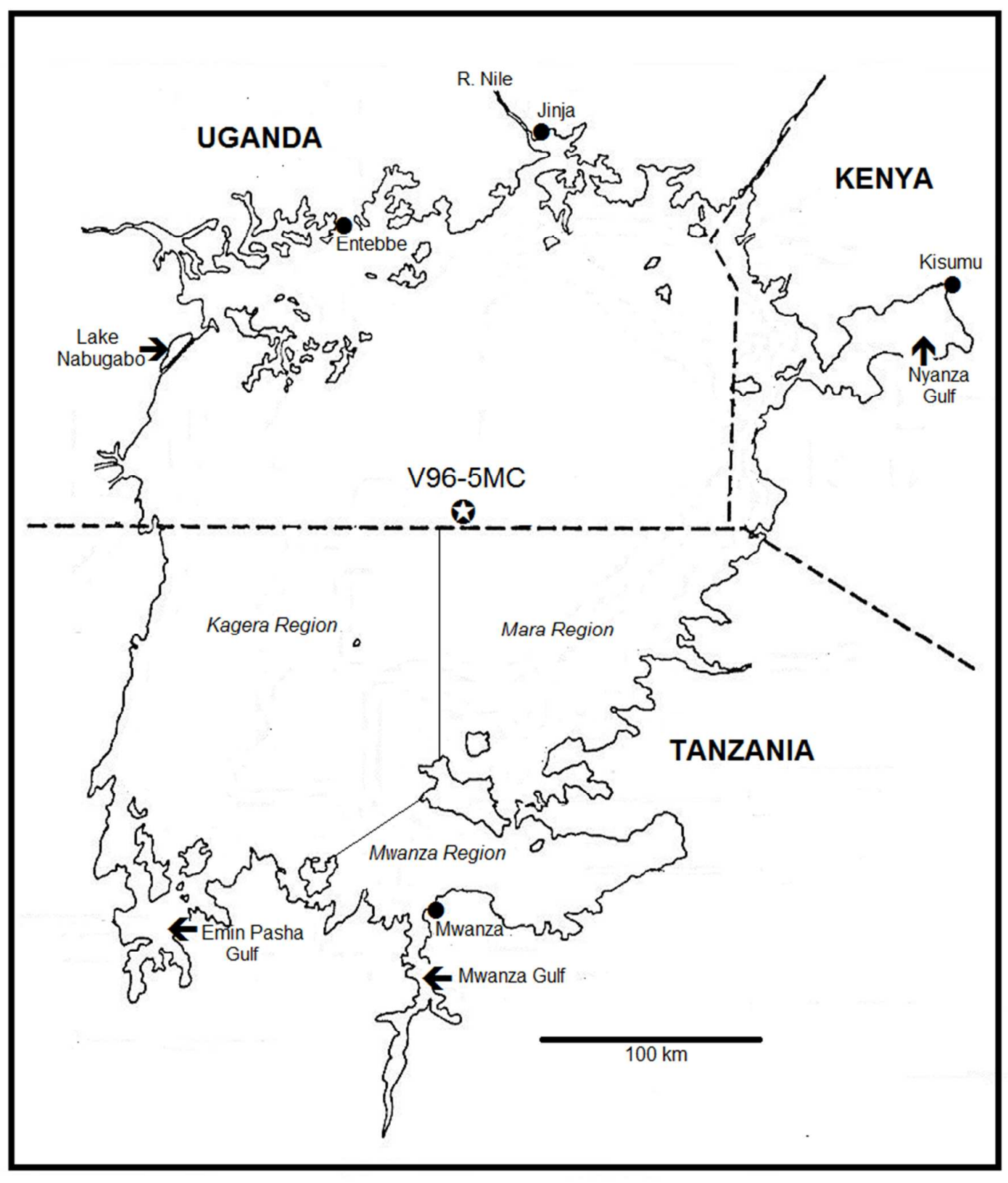

1436

1437

FIGURE 1. 
1439

1440

1441

1442

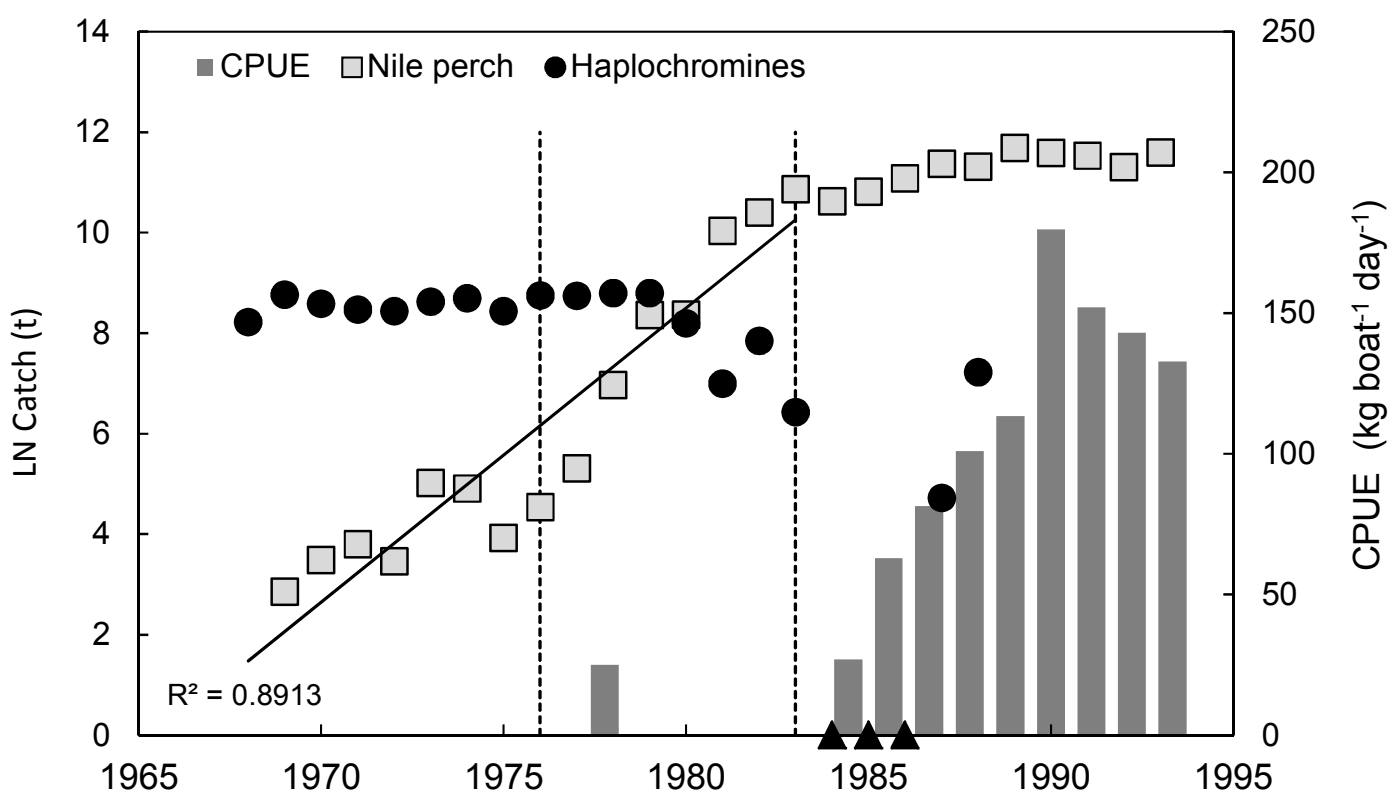

1443

1444 FIGURE 2.

1445 

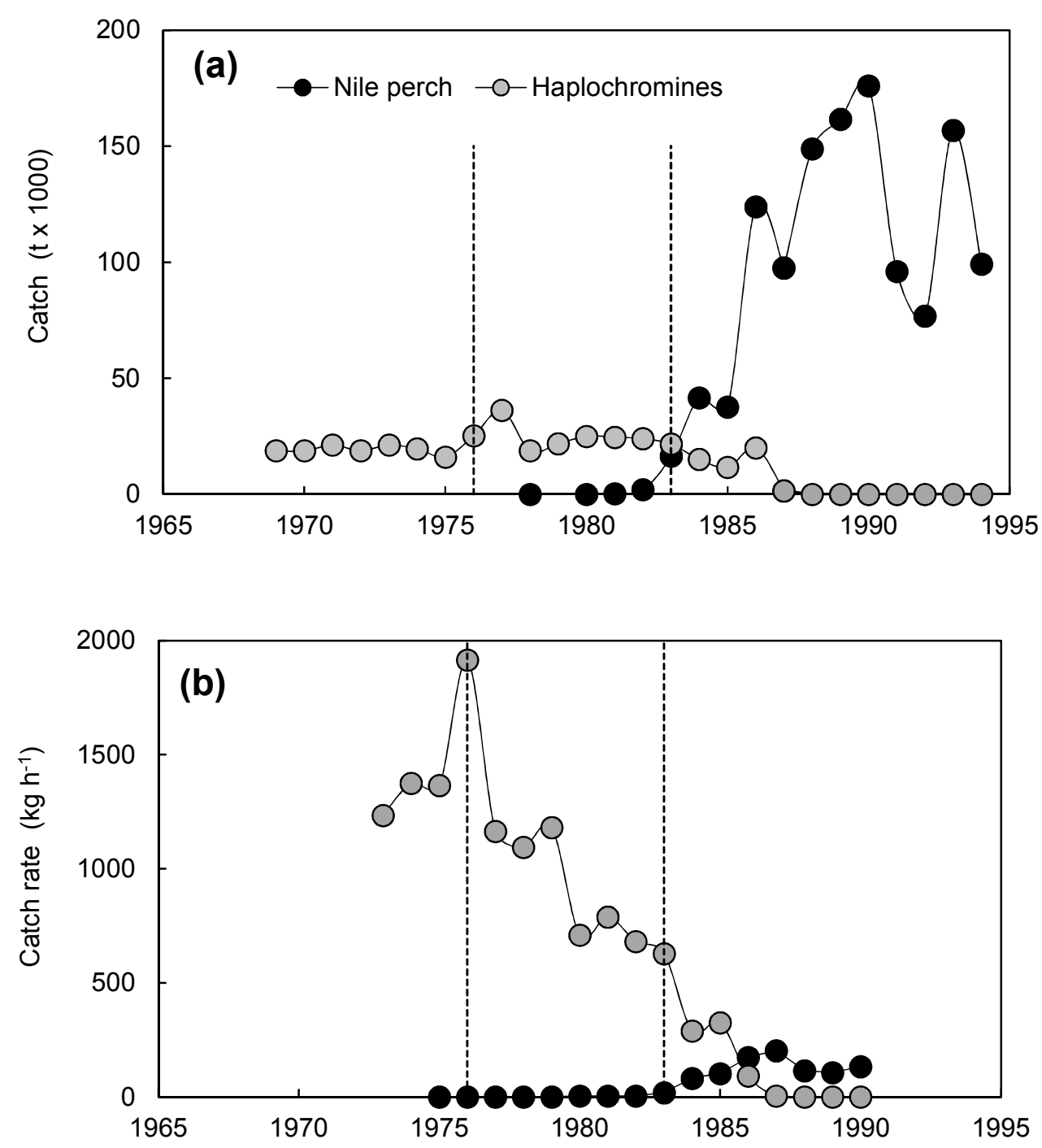

\section{FIGURE 3}

1447

1448 
North (Kenya, Uganda)
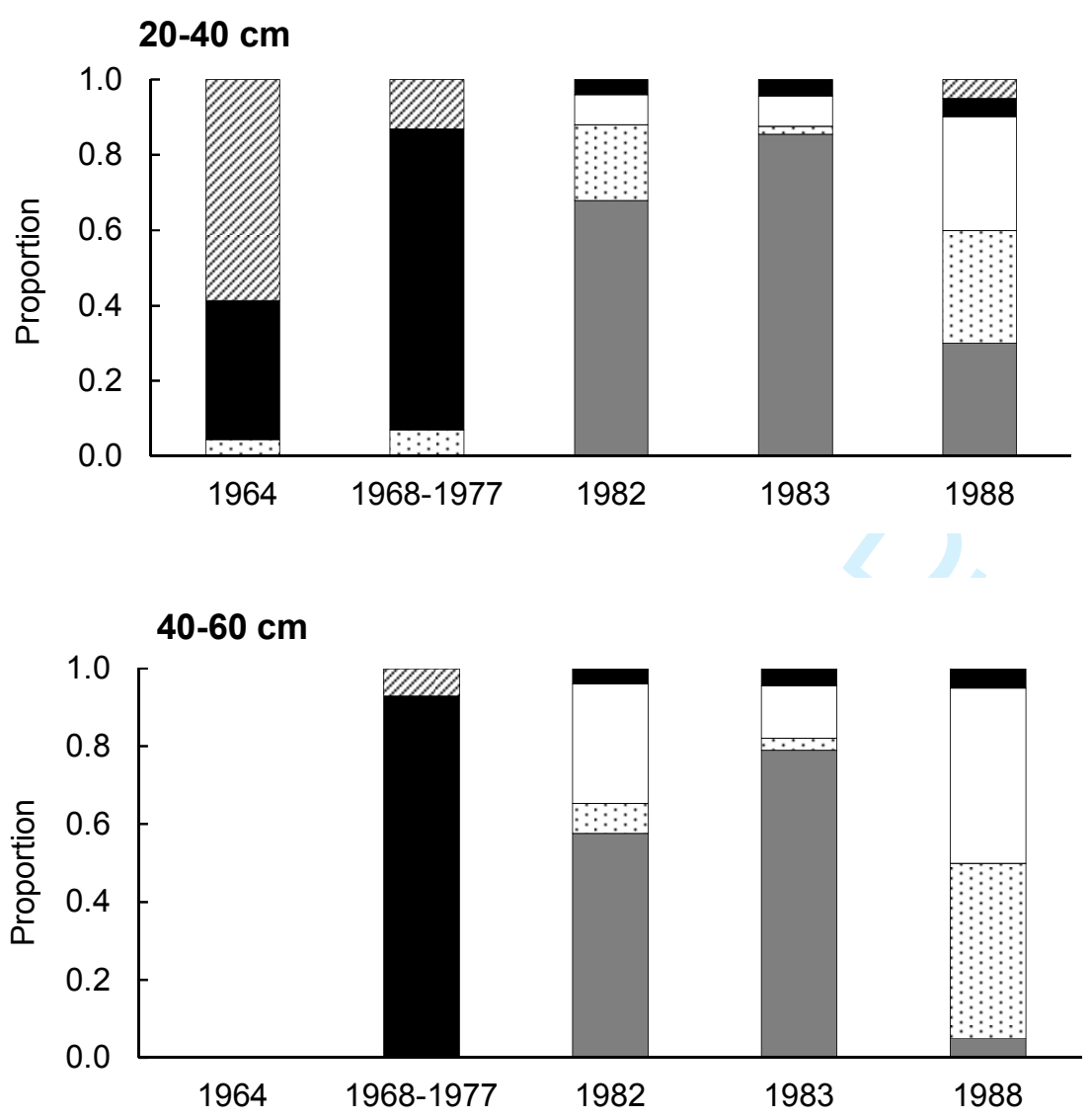

South (Mwanza Gulf, Tanzania)
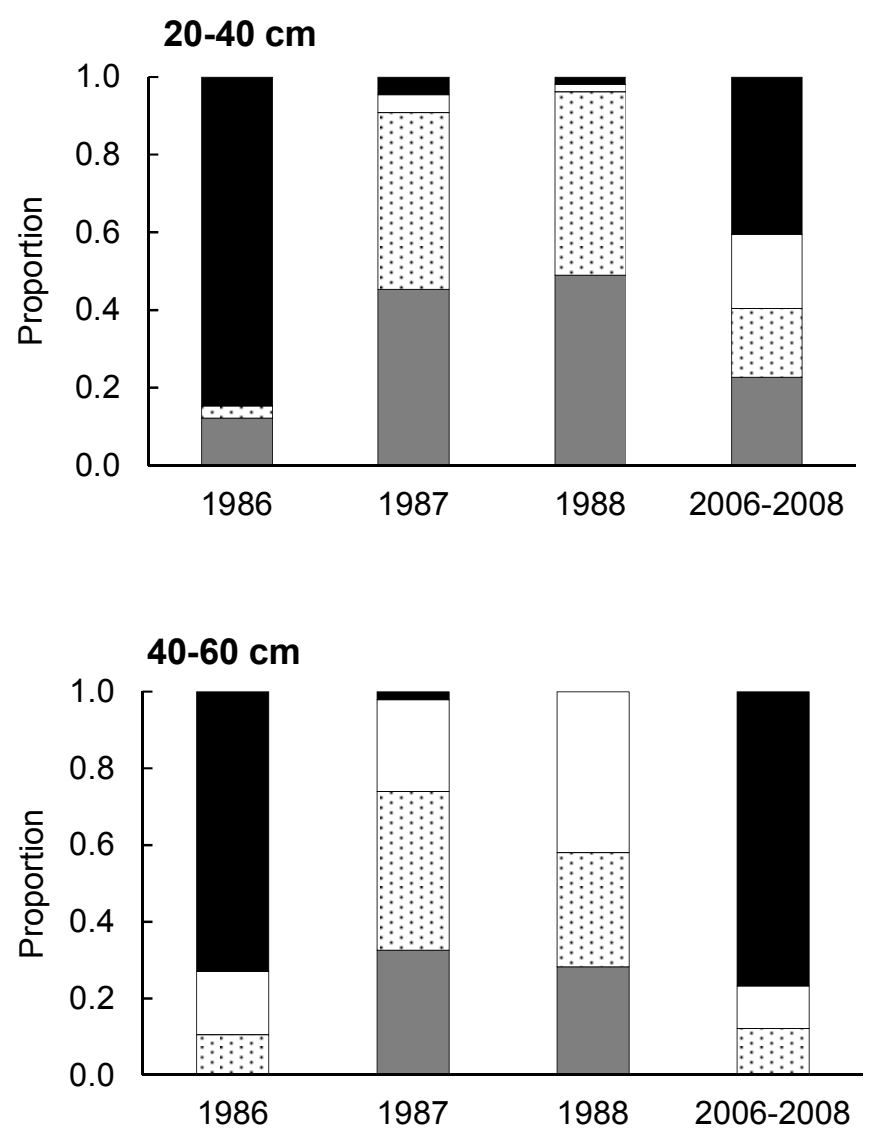

FIGURE 4

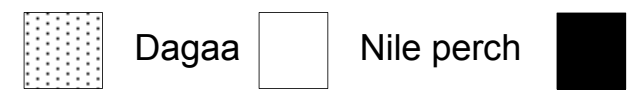

Haplochromines

Other fishes 

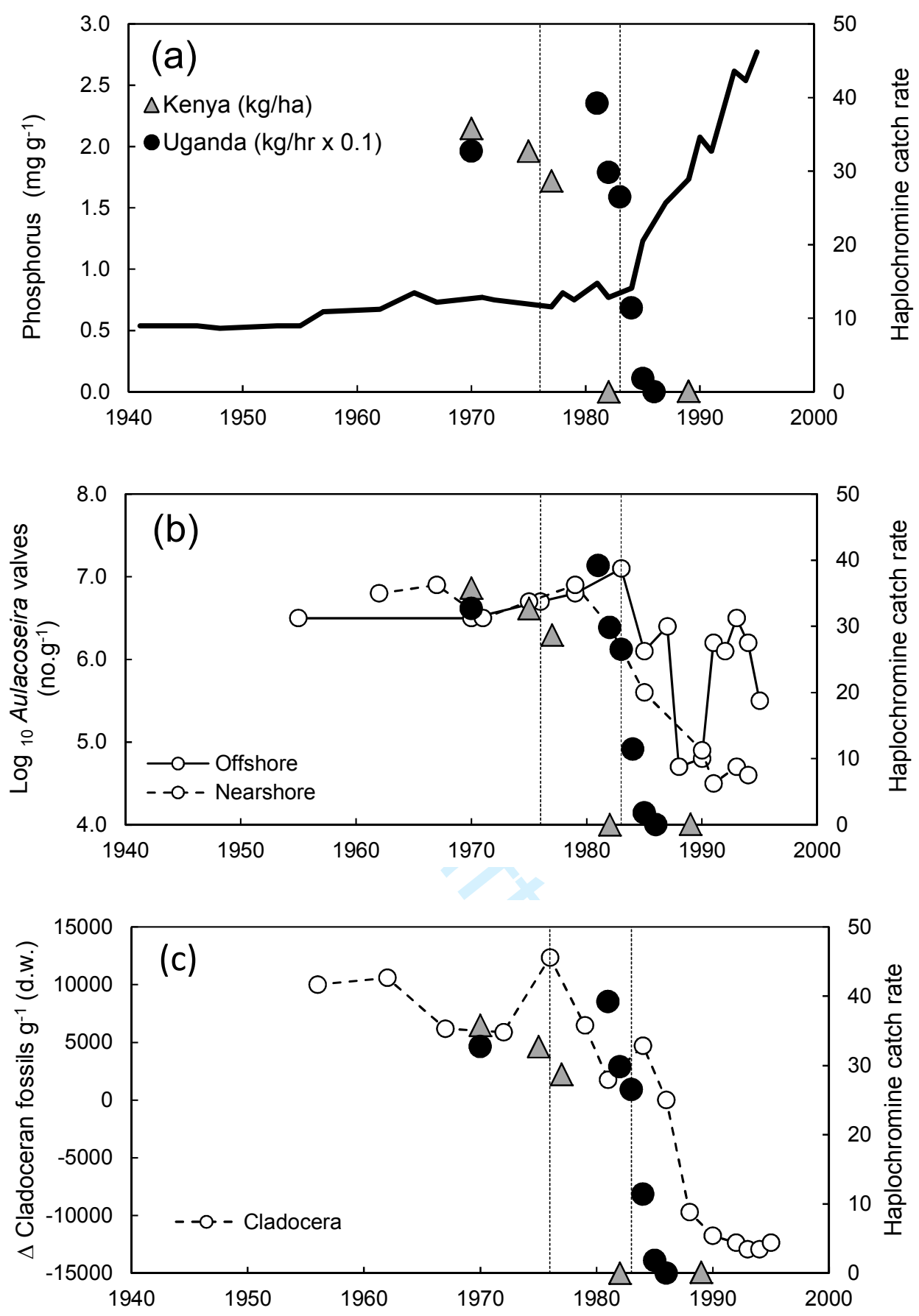

\section{FIGURE 5}


1450

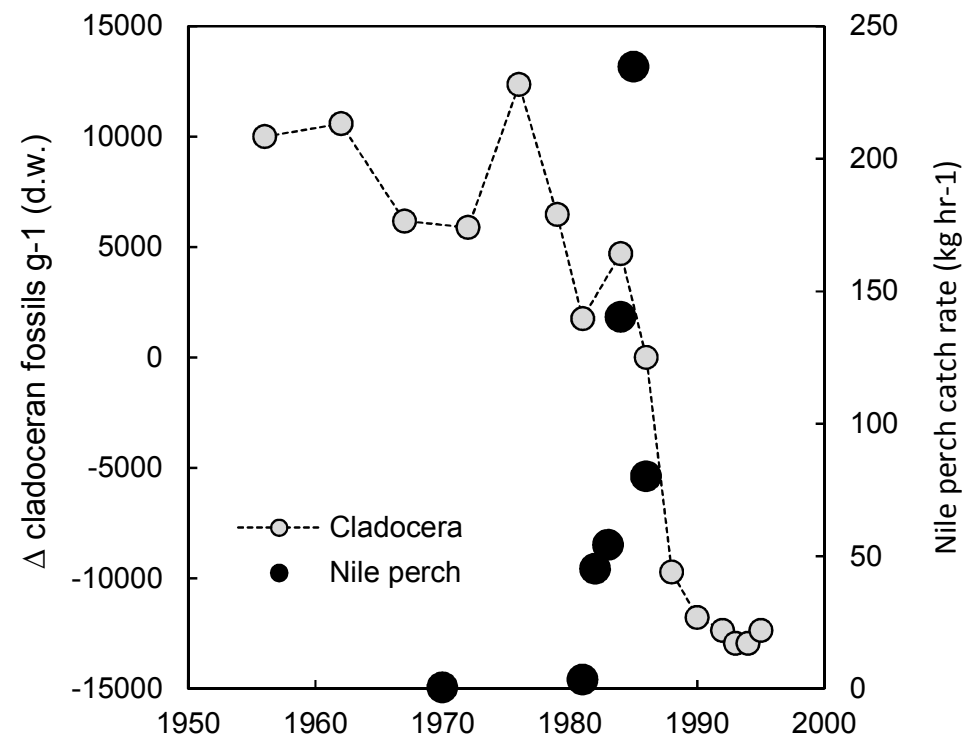

1451 FIGURE 6 
1452
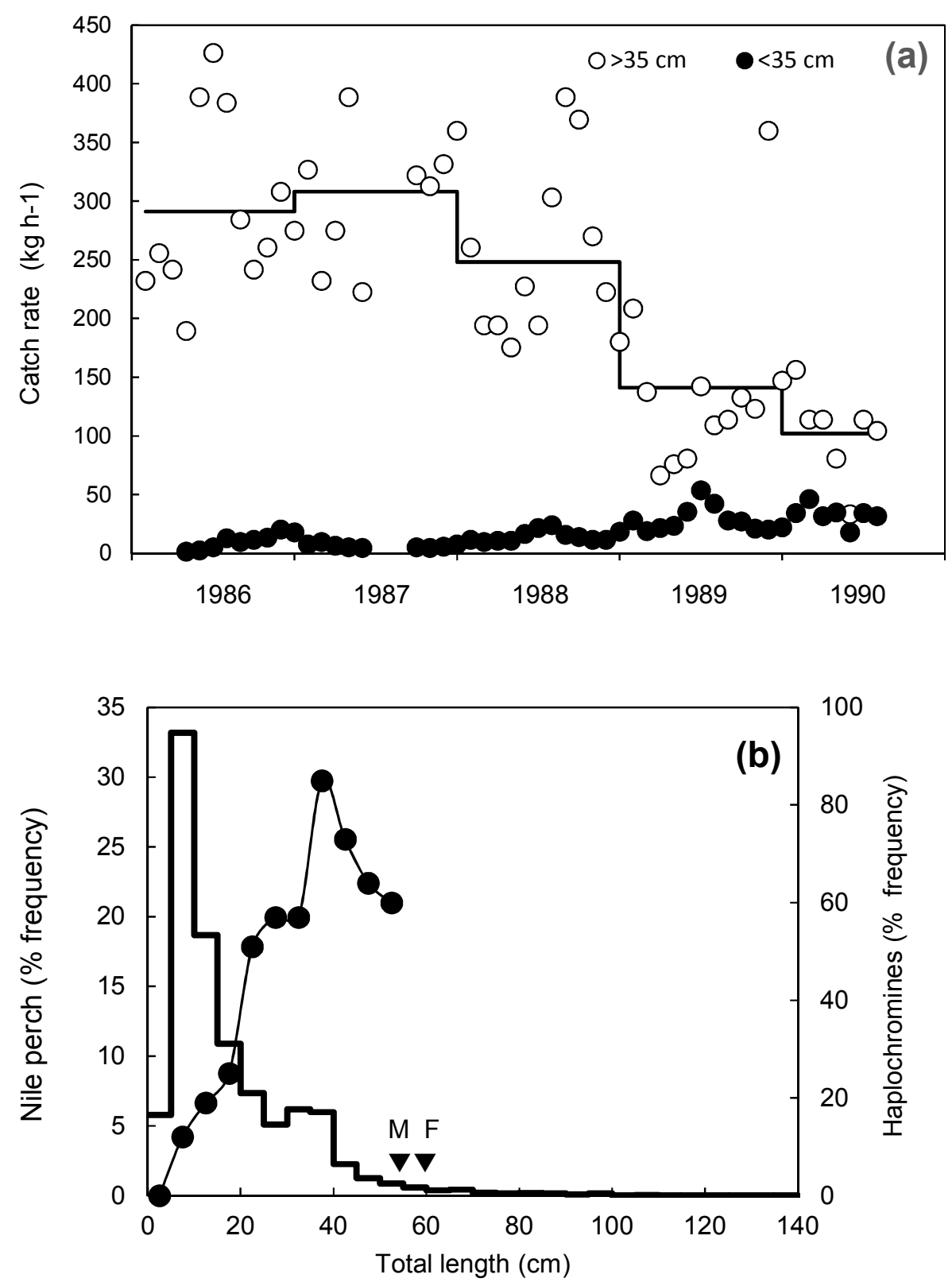

1453

1454 


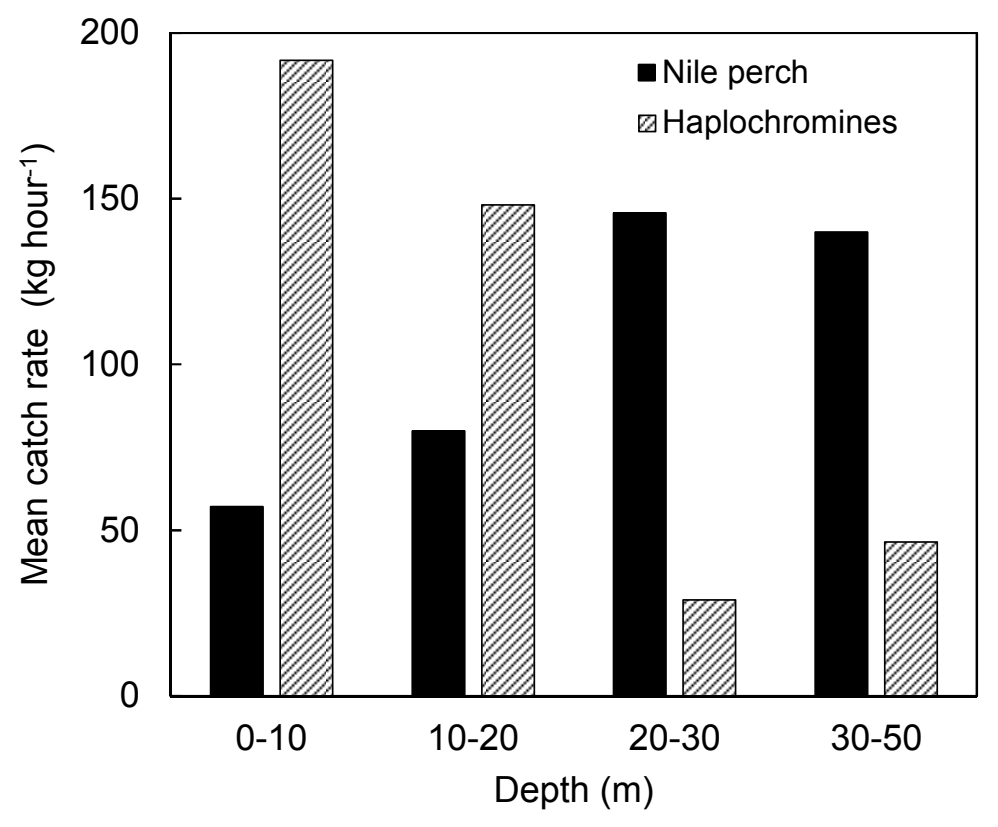

1458

1459

FIGURE 8 